\title{
PE. VAZ, A TRADIÇÃO OCIDENTAL E O BRASIL
}

Henrique Lima Vaz, the Western Tradition in the Brazilian context

Ivan Domingues *

Resumo: O objetivo é evidenciar o liame do pensamento e da obra de Pe. Henrique Cláudio de Lima Vaz (doravante Pe. Vaz e Vaz, simplesmente) com a chamada tradição filosófica ocidental, ao fazer seu escrutínio crítico, perguntar por sua originalidade e, por fim, indagar pelo modo como ele pensa o seu alinhamento com a tradição e a inserção do Brasil.

Palavras-chave: Pe. Vaz. Tradição filosófica ocidental. Filosofia grega. Filosofia medieval. Filosofia moderna. Filosofia no Brasil.

Abstract: This paper aims to clear up the relationship between Father Lima Vaz's thoughts and work and the so-called Western philosophical tradition. In order to do so, we will first critically examine his work and originality to, then, see how he considers both his alignment with that tradition and its insertion in the Brazilian context.

Keywords: Father Lima Vaz. Western philosophical tradition. Greek Philosophy. Modern Philosophy. Philosophy in Brazil.

* Professor do Departamento de Filosofia da Universidade Federal de Minas Gerais (UFMG). Artigo recebido em 03/03/2021 e aprovado para publicação em 5/03/2021. 


\section{Introdução}

Oom muita honra, convidado por Pe. Mac Dowell, aceitei participar da celebração do centenário de nascimento de Pe. Vaz, promovida pela revista Síntese e que ora vem a lume nesta edição especia ${ }^{1}$

Em duas outras ocasiões tive a oportunidade de me dirigir à obra do filósofo, com a intenção de restituir seu significado profundo, lembrando aos leitores que fui seu aluno nos famosos cursos de pós-graduação que ele ministrou na UFMG na década de setenta, quando o PPG ainda estava no início, em nível de mestrado, do qual ele foi o primeiro coordenador. Mais tarde, já professor do Departamento, eu participei por uns tempos de seu círculo de discussões, quando ele já estava na FAJE e eu pude ver de perto o que ele pensava sobre temas do momento ou da atualidade. Passados alguns anos, depois de um certo afastamento, eu vim a público duas vezes, como referenciado, e manifestei minha opinião sobre o seu pensamento e sua obra que eu tanto admirava. A primeira ocasião, tendo como efemérides as celebrações dos 60 anos da Faculdade de Filosofia da Companhia de Jesus e dos 80 anos de Pe. Vaz, precisamente um ano anos de sua morte, quando proferi a palestra "A crise da verdade e o sujeito ético" e depois publicada no livro coletivo organizado por Pe. Mac Dowell Saber filosófico, história e transcendência, que veio a lume pela Loyola em 2002. A segunda ocasião, em um dos meus mais recentes livros, Filosofia no Brasil - Legados e perspectivas, publicado em 2017 pela Editora UNESP, ao longo do qual eu me referi a Pe. Vaz mais de uma vez, ao me ver às voltas com o eminente pensador, erudito de vistas largas e um verdadeiro scholar, bem como, e antes de tudo, com o Vaz político, mentor da JUC e da AP e eminente intelectual público.

Agora, ao voltar ao jesuíta ilustre nesta nova oportunidade, vinte anos depois, desta feita frente à importante efeméride do centenário de seu nascimento, eu gostaria de colocar o foco sobre um ângulo diferente do pensamento e da obra de Pe. Vaz, o qual irá repercutir diretamente sobre a sua atuação como intelectual público e como eminente filósofo, ao considerar duas coisas:

1 a movimento de mão única do fluxo das ideias da Europa para essa parte do hemisfério, oriundo de vários centros do velho continente, especialmente França, Inglaterra, Alemanha, Bélgica e Itália, e se espalhando em vários pontos do nosso país;

$\mathbf{2}^{\mathbf{a}}$ a atitude dos meios acadêmicos frente às ideias vindas da Europa, tipificada em cinco categorias: [i] a atitude de alinhamento e de reverência; [ii] a

\footnotetext{
${ }^{1}$ Agradeço a Pe. Mac Dowell, Marcelo Perine, Carlos Drawin e José P. Giovanetti pelas interlocuções sobre a biografia e a obra de Pe. Vaz em diferentes etapas da elaboração do presente estudo
} 
atitude de assimilação e de independência crítica; [iii] a atitude ideológica de apropriação e instrumentalização política; [iv] a atitude hipercrítica de suspeita e defenestração da matriz europeia, como em diferentes vertentes do pensamento decolonial dos dias de hoje, não na época de Pe. Vaz; [v] em contraste com as anteriores, de brasileiros frente à Europa, a atitude dos europeus aqui atuantes em relação ao Brasil, oscilando entre a missão empática de civilização e a experiência de estranhamento e desidentificação, não faltando nem mesmo brasileiros nestas hostes.

A primeira ordem de considerações, como é sabido, num primeiro momento da história de nosso país - e num tempo em que o país não existia ainda, o Brasil Colônia -, levará ao grande fluxo das ideias da Ibéria, Espanha e Portugal até esta parte do hemisfério, a saber: o fluxo da segunda escolástica proveniente de Coimbra e numa menor escala de Salamanca e suas universidades famosas. Num segundo momento, já no período de pós-independência, séc. XIX, haverá a troca da Ibéria por outros centros da Europa, especialmente França no início, seguindo-lhe décadas mais tarde Alemanha e Inglaterra. Da simbiose desses fluxos e áreas de influência resultará o que poderia ser chamado de matriz europeia, devendo para ela ficar completa somarmos às correntes modernas do pensamento do velho continente para essa parte das Américas as heranças da tradição greco-romana e da idade média latina - esta última conforme propõe, aliás Pe. Vaz, ao considerar que a idade média bizantina ficou para trás e não teve maiores impactos na trajetória do pensamento tardo-medieval e mais ainda moderno.

A segunda ordem de considerações, menos óbvia, nos levará a introduzir nesses fluxos das ideias mais de um recorte, ao modo de distinções conceituais ou categoriais, e antes de tudo ao colocar o foco no receptor das ideias e nas atitudes possíveis do intelectual radicado na Colônia - e isto, como mostrei em Filosofia no Brasil, ao falar dos ethei da intelligentsia brasileira, uma vez passada a época da réplica e transplantação pura e simples das instituições e ideias da Ibéria para cá, por obra e graça da Companhia de Jesus:

[i] a atitude de alinhamento e de reverência, em suas diferentes vertentes, desde a do diletante, ao dar ensejo aos modismos sobretudo parisienses e suas réplicas em nossos meios, como foi comum no séc. XIX, passando pelo alinhamento doutrinal e ideológico, com enraizamentos nacionalistas, ao buscar uma filosofia de raiz, até a atitude do scholar, com sua expertise, mas não menos reverencial e subalterna frente a tudo aquilo que vem do hemisfério norte, incluindo a Europa e os Estados Unidos: este foram os casos de Gonçalves Magalhães, Tobias Barreto e Farias Brito no Brasil Império e na República Velha (1 $1^{\underline{a}}$ vertente), somando os exemplos de Miguel Reale e Antônio Paim, com Miguel Reale alinhado ao germanismo na extensão do culturalismo de Tobias Barreto e Antônio Paim abrindo caminho ao pensamento luso-brasileiro ( $2^{\underline{a}}$ vertente), e como eles, alinhados 
ao hemisfério norte, mas com maior lastro e densidade sociológica, milhares de scholars ou especialistas disciplinares nos dias de hoje ( $3^{\underline{a}}$ vertente);

[ii] a atitude de assimilação e de independência crítica, já notada no Pe. Vieira, ao usar as ferramentas da segunda escolástica para pensar a situação do Brasil Colônia - especificamente, com os ameríndios e os afrodescendentes na linha de frente, ao lado do colonizador europeu branco, num tempo em que o alinhamento da Colônia com a Metrópole nunca foi posto em xeque -, e que irá passar por um processo de adensamento e alargamento de independência crítica no período de pós-independência, sobretudo no curso do séc. XX: estes serão os casos de Pe. Vaz, Giannotti, José Henrique Santos, Marilena Chauí, Cruz Costa e de outros tantos, ao se colocarem na extensão da matriz europeia, como herdeiros da tradição ocidental, mas sem a reverência e a submissão dos representantes do primeiro grupo (acerca de Cruz Costa, estou pensando no depoimento que ele concedeu a Ladusãns e posteriormente publicado no livro organizado pelo jesuíta, precisamente no fim do depoimento quando o uspiano ilustre diz que sua posição como historiador da filosofia é de independência intelectual²);

[iii] a atitude ideológica de apropriação e instrumentalização política, dentro e fora da filosofia, à esquerda ou à direita, como mostrou Cruz Costa ao distinguir em nossos meios, como figuras prevalecentes, os glosadores de diferentes épocas e proveniências, às voltas com comentários de textos, entre os quais poderíamos encontrar os scholars acima referidos (1 $1^{\underline{a}}$ atitude), e os instrumentalizadores, caracterizados por usar as ideias como armas de guerra ou "equipamentos de campanha", como ele prefere ${ }^{3}$ : encontrando entre estes, diga-se, à direita do espectro político, os positivistas do séc. XIX e o grupo de Miguel Reale e Antônio Paim na segunda metade do séc. $X X$; à esquerda, os marxistas do séc. XX, os isebianos do Rio de Janeiro dos anos cinquenta e sessenta do XX e mesmo, como variante, os chamados intelectuais públicos - também eles engajados, em busca de uma eficácia da aplicação das ideias e de seus frutos na realidade circundante, mas caracterizados por uma certa distanciação frente às ideologias e às ações partidárias, posto que com um raio de atuação e independência bem mais amplo do que intelectuais orgânicos do partido, como vimos no meu livro Filosofia no Brasil (Exemplos: o próprio Pe. Vaz, referido pelos estudiosos como mentor da JUC e de seu braço político, a AP, qualificativo que ele recusa, porém reconhece o duplo vínculo, segundo ele informal, havendo ainda Marilena Chauí, ligada ao PT, mas antes de tudo uma scholar, com interesses filosóficos variados e eminente especialista de Spinoza);

\footnotetext{
${ }^{2}$ LADUSÃNS, S. Rumos da filosofia atual no Brasil - Em auto-retratos, Loyola, 1976, v. 1.

${ }^{3}$ CRUZ COSTA, J. O pensamento brasileiro sob o império, in: HOLANDA, S.B. (Org.). História da civilização brasileira, v. II, t. 3 - O Brasil monárquico. São Paulo: Difel, 1976, p. 323-324.
} 
[iv] a atitude de suspeita, repúdio e defenestração da matriz europeia, como nas vertentes mais hards do pensamento decolonial dos dias de hoje, na esteira dos chamados estudos culturais dos Estados Unidos, levando ao questionamento mais amplo e contundente do logocentrismo europeu e ocidental, visto como associado ao projeto ocidental de colonialismo de todos os tipos e proveniências, incluindo a colonização epistêmica: não podendo haver alinhamento à matriz europeia, nem culto ou reverência à tradição ocidental, o que se assistirá com o advento do pensamento decolonial será a postulação de uma reversão de atitudes e de perspectivas, ao modo de heterotopias e retorsões, em paralelo à busca das raízes propriamente americanas das ex-colônias espanholas, com o recentramento, nesta parte do hemisfério, do pensamento ameríndio, na esteira de Eduardo V. de Castro, ou do pensamento afrodescendente, iniciado com Abdias Nascimento e Lélia Gonzalez, e continuado com Djamila Ribeiro em nossos dias;

[v] em contraste com as anteriores, de brasileiros frente à Europa, a atitude dos europeus aqui atuantes em relação ao Brasil, ao deixarmos à parte os viajantes e naturalistas em suas estadas nestas paragens no curso do séc. XIX, mas sem contato e ação em nossos meios acadêmicos, como Saint-Hilaire, oscilando aqueles europeus entre a missão empática de civilização e de assimilação e a experiência de estranhamento e desidentificação: dentre estes europeus, numa das vertentes, Lévi-Strauss nos tempos em que ele fez parte da Missão Francesa, à época da fundação da FFLCH da USP, dos quais ele forneceu um instigante relato no início dos Tristes trópicos, havendo ainda Jean Maugüé na Seção de Filosofia da mesma Faculdade, que sempre teve o Brasil e São Paulo como temas de suas aulas, numa atitude de acolhimento e abertura intelectual, como mostraram Antonio Candido, Cruz Costa e Gilda de Melo e Souza; e em outra vertente, depois de passar mais de duas décadas por aqui, tem lugar o estranhamento e a desindentificação, levando à ruptura e à decisão de ir embora. Este foi o caso de Vilém Flusser, como ele deixa claro no artigo "Miguel Reale, um testemunho ${ }^{4}$, seguido de outros tantos, menos conhecidos, na esteira de Feynman no campo da física, como mostra em suas conferências no Rio de Janeiro nos anos cinquenta, em meio a nossos gaps e atrasos, inclusive práticas pedagógicas, frente ao hemisfério norte - e como será o caso, aliás, de muitos brasileiros, que decidirão ir embora e arranjar suas vidas alhures.

Diante deste quadro abrangente, podendo ainda um espírito analítico encontrar outras variantes e combinações, proponho fixar nossas atenções no caso muito especial de Pe. Vaz. Antes de mais nada - ao modelar as cinco atitudes e os enquadramentos dos filósofos, nacionais ou não, consignados acima -, eu tinha em mente, como referido, os ethei da intelligentsia

${ }^{4}$ Publicado na Revista Brasileira de Filosofia, jan.-fev.-mar., vol. XLII, fasc. 173, 1994, p. 7-14. 
brasileira, da época colonial aos nossos dias, na esteira da ideia de intelectualidade tipificada por Mannheim. No meu livro, Filosofia no Brasil, o leitor não encontrará uma correspondência direta entre uns (ethei) e outras (atitudes), por eu não ter tratado do estrangeiro ou do brasileiro que desistiu de tudo e foi embora, numa atitude negativista e demissionista. Da mesma forma que não considerei o hipercrítico e negacionista que repudia tudo que faz lembrar branquitude e europeísmo, ao colocar raças e etnias num primeiro plano, porém com sinais trocados. De resto, sem qualquer perspectiva unificadora tanto do país em que vivemos - por não haver um "nós" coletivo e reconciliado como nação, que nunca fomos no passado, com a colônia escravista nascendo cindida, ao gravitar em torno da casa-grande e da senzala, e nem mesmo como projeto, como país do futuro, futuro que foi cancelado e não se avista mais no horizonte - quanto das produções intelectuais em sua diversidade: concretamente, produções não só da filosofia em sua profusão de gêneros literários, mas igualmente da ciência e da literatura, como não se tardou a verificar, abarcando em filosofia o paper, o tratado e o ensaio. Trata-se, portanto, de um tópico novo em minhas incursões na filosofia brasileira, numa tentativa de afinar as antigas, bem como de criar novas ferramentas intelectuais para pensar a difícil questão de nosso alinhamento com a matriz europeia, comportando mais de uma atitude, indo da reverência ao repúdio. Ora, de nenhuma maneira esta será a alternativa e a convicção pessoal de Pe. Vaz, que era nestas matérias não um ensaísta ou um pós-modernista, digamos assim, mas um tradicionalista e um filósofo à antiga, um metafísico e um cosmopolita, em suma - e, desde logo, alinhado à tradição ocidental e ao jeito tradicional de fazer filosofia consignado por Platão e Aristóteles já na antiguidade, passando por Tomás de Aquino na idade média, até chegar a Hegel na era moderna, ao retomá-los e cuidar de reatualizá-los e trazê-los para o mundo de hoje.

Com essas ideias em mente, vou cumprir o seguinte itinerário nas páginas que seguem, esperando que, ao atingir o fim do percurso, eu consiga deixar claros tanto o alinhamento do jesuíta com a tradição filosófica - um alinhamento crítico e independente, como eu disse antes -, quanto as realizações de um pensador instigante, destemido e original, às voltas com a agenda universal da filosofia e ao mesmo tempo inquieto e atento frente aos problemas de nosso país e à agenda da filosofia brasileira.

Começarei, então, por considerar o depoimento ao livro de Ladusãns, que me servirá de fio condutor e em cujo registro autobiográfico se pode ver uma espécie de espólio intelectual, quando ele tinha 55 anos, mas já com a carreira coroada. E isto, efetivamente, ainda que só tenha principiado a publicar seus principais livros, não mais artigos de circunstância - vários deles já reunidos em duas publicações vindo a lume em 1967 e 1968 -, mas livros compondo a unidade de obra autoral, estes mais de dez anos depois, começando por Escritos de filosofia I em 1986 e chegando em 2020 
à marca impressionante de 14 novos livros, vários deles póstumos, sem contar os cerca de 192 artigos publicados, alguns deles revistos e republicados em duas ou mais oportunidades ${ }^{5}$.

Em seguida, irei examinar as entrevistas, que foram muitas, e em especial duas que vieram a lume já no fim de sua vida, como as concedidas [i] à revista da USP Cadernos de Filosofia Alemã, em 1997, indexada como Filosofia e forma de ação, título que aparece encabeçando a notícia de Franklin Leopoldo e Silva, e [ii] ao livro coletivo organizado por Marcos Nobre e José Marcio Rego e intitulado Conversas com filósofos brasileiros, vindo a lume em $2000^{6}$.

Por fim, sem poder aprofundar os livros, fora de cogitação para os limites do paper encomendado, irei considerar inúmeros artigos publicados ao longo das décadas e reunidos em três diferentes vertentes de sua vasta produção.

Numa escala maior, a vertente de sua produção como pensador internacional e alinhado ao mainstream da filosofia mundial, se é que existe um tal mainstream, senão a uma parte significativa dele, ao considerar uma de suas matrizes ou tradições intelectuais, alinhadas ao platonismo, ao pensamento católico e ao idealismo alemão.

Com este propósito, fiz a prospecção de três artigos que eu considerei essenciais para a montagem do meu argumento, mais além da notória e reconhecida afiliação de Vaz ao platonismo, ao tomismo e ao hegelianismo, reconhecida nas entrevistas acima, assim como no depoimento ao livro de Ladusãns. Iniciando a prospecção pelo seminal "Itinerário da ontologia clássica", publicado na revista Verbum em 1954, republicado em Ontologia e história, e que lhe abriu o caminho: nele vamos encontrar o jovem filósofo com seus 33 anos ladeado de Platão, Aristóteles e Tomás de Aquino, quando iniciou a modelagem do esquema onto-teológico da metafísica tradicional e em que ele enxerga o núcleo duro não só da metafísica, mas da própria filosofia in extenso, incluindo a ética e a antropologia filosófica. Seguido de "Presença Filosófica de Tomás de Aquino no horizonte filosófico do século XXI", vindo ao público pela revista Síntese em 1998 e depois republicado em Raízes da modernidade em 2002: nele novamente é o esquema da onto-teologia que está em jogo, fundado na homologia e co-pertença da filosofia e da teologia - não se trata nem da ancilla, nem da separação, nem da subordinação da religião à filosofia, como queria Hegel -, e que será trazido para a modernidade, encontrado em Hegel e condenado por

\footnotetext{
${ }^{5}$ Para as referências às obras de Pe. Vaz, ver Referências bibliográficas. Havendo republicações de artigos em livros, prevalecerão os livros, com a explicitação dos artigos em apreço, em observância às indicações firmadas no corpo do texto. Artigos e estudos apontados, mesmo que não referenciados em rodapé, mas usados para o controle da argumentação, serão incluídos na bibliografia.

${ }^{6}$ NOBRE, M \& REGO. J.M. Conversas com filósofos brasileiros. São Paulo: Editora 34, 2000.
} 
Heidegger, levando-o de volta a Tomás de Aquino. E terminando com "Antropologia tripartida", publicado em Perspectivas Teológicas, em 1991, menos conhecido, e no entanto essencial, ao evidenciar o liame da antropologia vaziana com a metafísica clássica, aristotélico-platônica, bem como com a teologia e a filosofia cristãs: nestas, aparecendo na linha de frente o apóstolo Paulo (corpo, psiquismo e espírito), Agostinho (que na Trindade introduz a mente, latim mens, mais ou menos equivalente ao pneuma ou ao nous grego, mais tarde vertida como espírito) e Tomás de Aquino (ao falar da inteligência - glosada por Vaz mais tarde, em seu estudo publicado em 2000 sobre a mística e a tradição filosófica ocidental, como "inteligência espiritual" - e, como tal, aberta ao Absoluto e ao Transcendente).

Numa segunda vertente, as suas considerações sobre a filosofia no/do Brasil, das quais três artigos serão retidos: [i] "O pensamento filosófico no Brasil de hoje, publicado na Revista Portuguesa de Filosofia, de extração jesuítica em sua origem, hoje ligada à Universidade Católica de Portugal, à qual revista Pe. Vaz destinava de tempos em tempos parte de suas publicações; [ii] "Filosofia no Brasil, hoje", na origem uma conferência proferida na SEAF (Sociedade de Estudos e Atividades Filosófica), em 1976, no Rio de Janeiro, e publicada pela revista da Sociedade (Cadernos SEAF) em 1978; [iii] "O problema da filosofia no Brasil", proveniente da aula de conclusão do Curso de Extensão sobre Filosofia no Brasil, preferida no Departamento de Filosofia da UFMG em 1981 e publicada na revista Síntese em 1984.

Numa terceira vertente, ao concluir o ensaio ${ }^{7}$, tratarei de elucidar o liame dessas investidas de Pe. Vaz no pensamento filosófico brasileiro com suas incursões políticas como intelectual público visando a transformação da realidade brasileira, na época em que ele fora ligado à JUC e à $\mathrm{AP}$, na primeira metade dos anos sessenta. Tratava-se de completar o perfil do pensador, ao expandir as análises já encaminhadas em Filosofia no Brasil, e, com este intuito, três documentos se revelaram essenciais: [i] "Ação popular: Documento-base", publicado como artigo pela revista Verbum, ligada à PUC-Rio, em 1964, que já vinha circulando um ano antes, desde o $2^{\mathrm{o}}$ Congresso da AP, em papel mimeografado, sem autoria assumida, mas do qual se sabe Pe. Vaz foi o autor de dois capítulos fundamentais: o

\footnotetext{
${ }^{7}$ Termo que eu prefiro, em vez de artigo, por caracterizar minha homenagem ao filósofo, não pelo aparato metodológico e a circunscrição de um tema único e controlado da hipótese, mas pela tentativa de abrir novas clareiras no campo de problemática e arriscar novas hipóteses em busca do significado do conjunto da obra, à luz de sua relação com a tradição filosófica: assim, não apenas o escopo é mais amplo do que o chamado paper científico, em seu aspecto exegético ou historiográfico que prevalece nos artigos de filosofia, mas a própria metodologia seguida me levou a considerar, mais além da minha experiência pessoal, notas da biografia do autor, abarcando registros dele próprio e consultas a remanescentes de seu círculo, em busca do embasamento das hipóteses e das análises. E desde logo, recaindo o empenho analítico não sobre os textos exclusivamente, mas, igualmente, sobre a figura do autor como sacerdote jesuíta e pensador independente: um ensaio de biografia intelectual, em suma.
} 
cap. I - Perspectiva histórica e o cap. 2 - Perspectiva filosófica: o homem e a história humana; [ii] o artigo "Cristianismo e consciência histórica", constituído de duas peças (I e II), publicadas pela revista Síntese em 1960 e 1961, e republicadas depois, acrescidas de um terceiro estudo sobre o mesmo assunto, mas com título diferente, em Ontologia e história; [iii] o artigo "A grande mensagem de João XXIII", publicado pela revista Síntese em 1963, com foco nas encíclicas Ad Petri Cathedram (1959), Mater et Magistra (1961) e Pacem in Terris (1963), tendo-me concentrado nas duas últimas.

Para tanto, vou dividir o ensaio em duas partes: a primeira, consagrada ao exame da maneira como Pe. Vaz vê a filosofia e sua relação pessoal com a tradição filosófica, ao se colocar na perspectiva do pensador universal radicado no Ocidente; a segunda, consagrada ao exame da maneira como Pe. Vaz vê o Brasil, se vê como brasileiro, percebe a inserção do Brasil e da filosofia brasileira na tradição filosófica ocidental.

\section{Alinhamento com a tradição filosófica}

Começo pelo depoimento de Pe. Vaz ao livro de Ladusãns. Desde o início saltam aos olhos o alinhamento do filósofo com a tradição filosófica greco-cristã, iniciada durante a sua formação em Nova Friburgo, RJ, na Faculdade de Filosofia da Companhia de Jesus (ele foi acolhido em 1938), onde recebeu uma iniciação rigidamente escolástica, como ele disse em mais de uma ocasião - e, desde logo, com Aristóteles e Tomás de Aquino na linha de frente, facilitado pelos mestres de rara competência que lá atuavam, bem como pelos manuais famosos, tendo concluído o curso de filosofia em 1945 (bacharelado) e a licenciatura um ano depois.

Em 1946, ele foi para Roma e iniciou na Gregoriana mais uma etapa de sua formação, quando começou seu curso de teologia, ordenou-se sacerdote em 1948 e obteve em 1950 sua licenciatura na ciência divina com a dissertação O problema da beatitude em Aristóteles e Santo Tomás. E o que é importante: agora, como antes, de corpo e alma na tradição, mas usando as ferramentas da Nouvelle théologie, como ele reconhece no depoimento, ao ressaltar que se tratava da releitura da Ética a Nicômaco de Aristóteles e das primeiras questões da Secunda secundae de Tomás de Aquino "com as chaves de interpretação oferecidas pelo Pe. de Lubac".

Por fim, terminando sua formação, ele concluirá seu doutorado em filosofia em 1953, com a tese De Contemplatione et Dialectica in Platonis Dialogis, datando daí a inflexão de seu pensamento na direção de Platão, porém sem abandonar Aristóteles, e iniciando também nesta época sua aproximação, ainda indecisa na ocasião, de Hegel e da dialética. No mesmo ano ele voltará para o Brasil, tendo como destino Nova Friburgo e a Faculdade 
Eclesiástica de Filosofia, desta vez como mestre, onde ensinará por cerca de dez anos, com os mesmos backgrounds, com os mesmos manuais, com as mesmas lições e com os mesmos exercícios da segunda escolástica ainda em curso, testemunhando a validez e a atualidade da Ratio Studiorum da Companhia de Jesus: vale dizer, a pedagogia dos jesuítas, da qual Pe. Vaz fala, de seus tempos de aprendizagem, com muita reverência e emoção, lembrando as "alegrias austeras" dessa época e as excelências do instrumental do "latim escolástico".

Tudo isso é amplamente conhecido dos estudiosos e leitores de Pe. Vaz e só estou me referindo a esses períodos e a essas datas para me situar, ao dispor sua formação e sua obra na linha do tempo, com suas continuidades e rupturas, com a tradição filosófica e seu alinhamento pessoal ao fundo de suas considerações. Tudo somado, cinco segmentos temporais, se adicionamos aos quatro intervalos referenciados no depoimento a Ladusãns, cuja contagem é interrompida em 1976, mais um outro, que vai da sua aposentadoria na UFMG, quando passou a atuar full time na Faculdade da Companhia de Jesus, depois FAJE, até sua morte em 2002. Assim, teremos:

[1] 1938-1945: graduação em filosofia na Faculdade de Filosofia em Nova Friburgo;

[2] 1946-1953: bacharelado e licença (equivalente eclesiástico ao mestrado) em teologia e doutorado em filosofia na Universidade Gregoriana de Roma, que era o principal destino do clero católico com vocação intelectual, teológica ou filosófica;

[3] 1953-1964: professor na Faculdade de Filosofia em Nova Friburgo, de onde saiu por problemas políticos, os quais serão evidenciados na sequência do ensaio;

[4] 1965-1985: professor na Faculdade de Filosofia e Ciências Humanas da UFMG, paralelamente ao tempo em que atuou na Faculdade Eclesiástica no Rio de Janeiro (1975-1981), tendo por um curto período atuado como professor do PPG de Filosofia da PUC-RJ, experiência interrompida quando da eclosão da crise de 1979 com o grupo de Antônio Paim e Anna Maria Moog Rodrigues;

[5] 1982-2002: professor na Faculdade Eclesiástica do Centro de Estudos Superiores da Companhia de Jesus, mais tarde FAJE, em Belo Horizonte.

Voltando para as continuidades, as inflexões e as rupturas encontradas nesses cinco períodos, se é verdade que Pe. Vaz até o fim de sua vida testemunhou sua enorme reverência em relação à tradição filosófica de onde veio e para onde voltou, ao reconhecer as excelências da formação clássica que ele recebeu e passou a ensinar até o fim de sua vida, não é menos exato que sua visão da tradição filosófica não tem nada de tradicionalista e de monolítica ou petrificada - e isto pela razão muito simples que tra- 
dição, conforme ele lembra (do latim tradere = entregar, passar, transmitir; traditio-onis = entrega e transmissão, como transmissão do conhecimento), vai junto com o presente e a atualidade, levando à distinção do passado vivo e do passado morto. Porém, como a filosofia se desenvolve em ciclos e a linha do tempo está sujeita a meias-voltas e mesmo a volteios completos, a transmissão da filosofia vai junto com a história e a história é memória e, também, esquecimento: este ponto é crucial e deve ser metodologicamente incorporado à reflexão do filósofo, como logo entendeu Pe. Vaz, por ver na rememoração ou anamnese a volta daquilo que foi esquecido e recalcado. Este, ao voltar à reflexão filosófica e se integrar a um novo contexto ou campo de problemática, irá abrir novos caminhos para a filosofia, servindo justamente como apoio e arranque da dialética das ideias que irá introduzir mediações no ponto de partida (o vivido imediato e rememorado ou atualizado) e elevará o vivido originário ao pensamento reflexivo ou ao intelectivo pensado, como na síntese hegeliana e na ideia platônica. Entendo que este ponto é fundamental e mais de uma ruptura e continuidade iremos encontrar ao longo do percurso.

Ao pensar a história da filosofia desde a antiguidade clássica, cujos grandes momentos deverão ser suprassumidos na grande síntese hegeliana, que é o saber absoluto e que nos dará a síntese da razão e da história ${ }^{8}$, Pe. Vaz em um de seus estudos consagrados à filosofia no Brasil (Cadernos SEAF, 1978) irá apontar dois começos da filosofia: [i] o começo grego, num dia que não se sabe qual exatamente e nem onde precisamente, mas - numa reconstrução livre do pensamento do filósofo mineiro - nos tempos arcaicos da antiga Grécia, em meio a diferentes povos sem unidade e cada qual com seu rei e seu reino, quando houve a crise do mito e a passagem ao logos, levando Pitágoras a cravar o nome de filosofia para este novo saber: a novidade, com efeito, consistindo justamente em distingui-la da antiga tradição sapiencial, com suas sentenças enigmáticas, e fazendo imperar a exigência de tudo trazer, ao dar as razões do logos, à luz do meio dia e ao crivo de um fórum de discussão universal; [ii] o começo latino ou, antes, medieval e ocidental latino, por não se tratar mais do oriente nem de Bizâncio, na esteira dos esforços dos primeiros pais da Igreja de acomodar a filosofia grega clássica e as exigências do logos universal - os crivos da razão e da demonstração - às verdades da cristandade e dos livros sagrados: verdades reveladas e artigos de fé, especificamente, tendo como máxima o famoso crede ut intelligas (creia para entender) de Santo Agostinho e em sua versão de Santo Anselmo (credo ut intelligam), dando passagem para outra fórmula de Santo Anselmo e que nos levará a São

\footnotetext{
${ }^{8}$ Trata-se do tema do último capítulo da obra Ontologia e história, reeditada em 2001 pela Loyola, quando passou a integrar a série Escritos de filosofia, vol. VI: especificamente, um capítulo inédito, escrito ad hoc conforme Vaz e intitulado $\mathrm{O}$ absoluto e a história, de notória ressonância hegeliana, mas evocando um Hegel ainda indeciso, com Marx, Husserl e Heidegger interpostos, havendo ainda Dilthey, Jaspers e Aron.
} 
Tomás de Aquino, justamente a fides quaerens intellectum (a fé que procura entender).

Como Pe. Vaz reconhece explicitamente no depoimento ao livro de Ladusãns, inscrevendo-se, como eu disse, de corpo inteiro na tradição filosófico-teológica medieval latina, com suas raízes bíblicas e helenísticas, ele tratará de executar, ao voltar para o Brasil em 1953, um programa de estudos no campo da metafísica que ele anunciará no $2^{\mathrm{o}}$ Congresso Brasileiro de Filosofia ocorrido em Curitiba em 1952 e publicado na revista Verbum em 1954: trata-se da comunicação "Itinerário da Ontologia clássica", que mais tarde passou a integrar Ontologia e história e segundo ele "pode ser interpretad[o] como a reconstituição [desse] itinerário pelos caminhos do pensamento clássico, de Platão a Santo Tomás, como o olhar lançado a partir de um ponto de chegada no qual, uma última vez, eu reencontrava a leitura marechaliana de Santo Tomás". Marechaliana, ou seja, a leitura de Joseph Maréchal, renomado jesuíta belga autor de $O$ ponto de partida da metafísica e dele conhecido desde os tempos de Roma. Uma obra segundo ele fundamental, trilhando os caminhos da ontologia clássica ou tradicional, mas desafiada pela ontologia cartesiana e moderna, com sua tabula rasa da metafísica escolástica e o cogito famoso no ponto de partida, evocado no título famoso. Um pouco como no jesuíta brasileiro, em cuja comunicação, depois capítulo, reconhece um novo enraizamento em sua ontologia: um enraizamento moderno, não só clássico ou medieval, ao se ver às voltas com as questões do sujeito e da consciência, levando-o a dizer que em suas reflexões havia "uma interrogação que podia assumir a forma de uma paráfrase da célebre interrogação cartesiana, pois se não me perguntava: quod vitae sectabor iter?" [Que estrada hei de seguir na vida?] sem dúvida me perguntaria: quod mentis [pensamento] sectabor iter?" (Ladusãns, op. cit., p. 304).

Ora, a primeira realização desse programa de pesquisa anunciado por Pe. Vaz naquela época, já de volta ao Brasil, foi levada a cabo - eu ousaria dizer - na referida Ontologia e história, que veio a lume em 1968 e será republicada em 2001, como lembrado: obra composta de 11 capítulos e dividida em duas partes, a primeira consagrada à ontologia geral, a segunda à filosofia da história, cujo outro nome é metafísica da história e da qual se pode dizer que, em seus propósitos, evidenciados nos estudos ali arrolados, é um capítulo da ontologia geral, como aliás a filosofia da natureza, e integrada em seus esquemas. E desde logo, com seu "fundacionismo", a expressão é de Pe. Vaz, tudo iniciando com A dialética das ideias no Sofista, prosseguindo com A metafísica da interioridade, centrada em Santo Agostinho, e havendo ainda o seminal Itinerário da ontologia clássica, todos de 1954 e os quais, tomados em conjunto, irão pavimentar o caminho. Mas que logo depois, desde meados dos anos cinquenta, ao acaso das solicitações e das publicações do período, iremos deparar com o nosso filósofo mais e mais às voltas com a filosofia moderna, como 
acabamos de dizer e ele mesmo reconhece: antes de tudo, ao se ver desafiado pela centralidade da filosofia do sujeito e do tema subjetividade, e, como tal, em seu núcleo duro, dando azo a uma nova ontologia com a ordem das essências colocada de ponta-cabeça (começando o filosofar com a res cogitans e o eu solipsista em 1a pessoa: Ego, Je e Moi), rompida com a transcendência dos escolásticos e imersa na imanência absoluta da consciência desde Descartes. Mas em que Vaz se vê desafiado a encontrar, ao dedicar ao menos três caps. da obra citada ao tema da consciência e da história - tema moderno por excelência, segundo ele -, as convergências e as acomodações com as heranças da ontologia clássica em suas matrizes grega e latina.

Trata-se de uma nova ontologia, com efeito, cujas categorias centrais, como ser, substância, essência e existência, se verão submetidas a inúmeras provas - verdadeiras provações e reviravoltas - em seu percurso moderno: à prova de Sartre e do existencialismo, como ele reconhece no depoimento a Ladusãns, que retomará a categoria existência numa perspectiva ateia e sem o embasamento das quididades e das essências da metafísica tradicional; à prova de Heidegger e do esquecimento do ser, ao radicalizar o programa da fenomenologia; e mesmo à prova de Descartes, com sua metafísica dualista e a redução da mens ao cogito e, por extensão, à psyché, sem esquecer de Hegel, em quem a centralidade e o escopo do espírito, depois da redução de Descartes (pura interioridade), se verão dilatadas e terão uma circunscrição bem mais larga ou extensa, para satisfação de seu leitor atento dessa parte do hemisfério.

Data mais ou menos dessa época o mergulho de Pe. Vaz nas águas profundas do pensamento moderno, e estou falando de pensamento moderno porque não é só a filosofia que está em jogo. Como logo veremos na sequência do depoimento a Ladusãns, vão entrar na linha de conta dessa importante fase do pensamento e obra do filósofo a Theologie nouvelle, em suas extrações francesa (De Lubac) e alemã (Karl Rahner). Sobretudo em sua extração francesa, com os dominicanos e jesuítas na linha de frente, no curso dos anos cinquenta e que iria repercutir profundamente nas mudanças da orientação da Igreja Católica protagonizada pelo Vaticano II, não sem antes condenar o Pe. de Lubac ao silêncio, por quem Pe. Vaz tinha uma enorme admiração. E numa outra vertente encontraremos a ciência moderna, com o filósofo mineiro enumerando entre os ascendentes cientistas do quilate de Poincaré, De Broglie e Heisenberg, bem como historiadores da ciência de primeira grandeza, como Duhem (também físico), Lenoble, Koyré e Brunschivcg, além de filósofos da ciência, como Mach e Bachelard, em sua maioria franceses: todos eles frequentados e ensinados nos cursos de Filosofia da Natureza proferidos pelo jesuíta ilustre na UFMG desde meados dos anos sessenta, cujos manuscritos encontram-se disponíveis para consulta no Memorial Padre Vaz. Mais tarde, ao expandir as sendas abertas pelos estudos das ciências, na esteira da filosofia das ciências, Pe. 
Vaz irá abrir um espaço cada vez mais amplo em suas reflexões sobre a modernidade para a filosofia da tecnologia, ao falar das tecnociências e do pensamento operatório, como em seu artigo seminal "Presença de Santo Tomás de Aquino no horizonte filosófico do séc. $\mathrm{XXI}^{\prime}$, já referido, não lhe tendo faltado outras ocasiões.

A essas listas de modernidades devem ser adicionadas o enorme acervo e a imensa influência da filosofia propriamente moderna - e eu não estou exagerando ao empregar os superlativos, pois é ele mesmo quem o diz com datas, nomes e tudo -, iniciada com o grande racionalismo dos séculos XVII e XVIII, protagonizado por Descartes e Espinosa, e concluída com Hegel nas primeiras décadas do século XIX, em cuja obra extraordinária, com suas mediações, ele vê o "Império do Meio do pensamento moderno" em filosofia, enxergando em Marx e na esquerda hegeliana, especialmente no marxismo, uma espécie de "província do hegelianismo em permanente estado de revolta".

Mas não é só: além do grande racionalismo, sua nova terra de adoção, Pe. Vaz reconhecerá seus alinhamentos com nomes consagrados do neotomismo e da mova escolástica, como Jacques Maritain, com sua enorme influência pelo mundo afora, incluindo-se o Brasil e o Vaticano, como é sabido, chegando ao ápice à época do Concílio Vaticano II. Soma-se ainda a influência de Emmanuel Mounier, cujo nome viu-se definitivamente associado ao "personalismo", corrente a que Pe. Vaz se via ligado, com enorme ascendência sobre o cristianismo social e o catolicismo de esquerda, devendo ser acrescentados ainda os nomes de Blondel, Sertillanges, Rousselot, Gilson e do próprio Maréchal, que não era francês, mas belga e francófono. Tão grande foi a influência desse agrupamento na conformação de seu pensamento - um agrupamento contemporâneo, ao fim e ao cabo, senão tardo-moderno, melhor dizendo - que Pe. Vaz irá dizer, num raro arroubo retórico, ele que sempre foi tão comedido e austero, que desde os tempos de Nova Friburgo a língua francesa era para ele e seus confrades, juntamente com o latim, "nossa língua-mãe filosófica".

Tudo isso é verdade e deve ser considerado, não certamente todo o universo do pensamento francês, havendo os materialistas, os ideólogos, os existencialistas e os pós-modernistas, contra os quais ele se insurge em posição de repúdio e combate. E o faz, devido às suas escolhas e aos seus alinhamentos, que são outros e com outras preferências: numa vertente, em defesa do grande racionalismo dos séculos XVII e XVIII, conforme já assinalado, com Descartes reinando entre seus representantes e havendo ainda os enciclopedistas; noutra vertente, precedida de Pascal, o assim chamado "espiritualismo francês", expressão que ele evita empregar, mas com o potencial de abarcar uma plêiade enorme de pensadores, como Maine de Biran, Bergson, Lachelier, Brunschvicg, Blondel, Mounier, Maritain e outros mais, inclusive no Brasil, como Jackson de Figueiredo e Alceu Amoroso Lima. 
Porém, nessa nova fase de seu pensamento, cujo início ele data de 1955 e que o leva de Descartes a Hegel, é o nome de Hegel que acabará prevalecendo, como foi mencionado, e antes de tudo por ser ele aquele filósofo que melhor o ajudou a achar a resposta para o seu problema, problema teórico e filosófico, mas também vital e existencial, como ele dirá ao fim do depoimento:

“Mas não é como historiador da Filosofia que me interesso por Hegel. Para mim, a sua obra e como o olhar mesmo do Saber absoluto, recapitulando ou levando a cabo a lembrança de uma longa história, e descerrando o horizonte de uma nova história que se vê face-a-face com a tarefa ingente - única tarefa propriamente histórica - de assumir-se a si mesma na reflexibilidade de uma Razão total. Alguns dos meus critérios de leitura de Hegel estão no artigo: "Cultura e ideologia: sobre a interpretação do cap. VI da Fenomenologia do Espírito", que a revista Kriterion, da FAFICH-UFMG, publicou no seu ํㅡㅇ 67 (1974).

A grande questão, para mim vital: como terá podido Hegel pensar, nos quadros da sua dialética da Razão, o Cristianismo como a "religião dos tempos modernos"? Como conciliar o Saber absoluto, imanente, ao desenvolvimento histórico, que nele conhece a hora meridiana em que se torna possível uma Ciência da Lógica, o pensamento do Sistema, com a transcendência cristã?"

Que fique claro: nesta tarefa ingente de, com a ajuda de Hegel, pensar o cristianismo como a "religião dos tempos modernos", levando-o a falar de "consciência histórica" e "subjetividade moderna", o interesse de Pe. Vaz pelo filósofo de Jena não é nem de historiador, como ele diz, nem de exegeta, poderíamos acrescentar. $\mathrm{E}$ isto porque aquilo que está em jogo em sua relação com o pensamento e a obra de Hegel é uma questão para ele "vital" que o interpela no fundo de seu ser como pensador, tendo chegado onde ele chegou depois de anos de formação e agora pronto para os grandes embates como pensador autônomo e independente: justamente, a questão de como conciliar absoluto e história ou saber absoluto e devir histórico, colocando a transcendência cristã acima da imanência laicizante moderna empunhada pelas diferentes vertentes das filosofias da consciência e do sujeito, problema que o desafiou desde sempre. Ou seja, desde os tempos que se passaram de sua saída de Nova Friburgo às Montanhas de Minas Gerais, quando ele colocou em primeiro plano a "consciência histórica", conforme vimos antes, e agora às voltas com a herança hegeliana da razão histórica e a Fenomenologia do espírito. Este é, portanto, o ponto e é este o embate de Pe. Vaz desde então, especialmente a partir de 1958, segundo a sua datação, ao colocar no centro da agenda filosófica a pauta de pensar os desafios da atualidade com as armas e as bagagens da ontologia clássica, cujo itinerário ele esboçou em 1954. E agora desafiada pelas urgências dos novos tempos - tempos ímpios, fundamentalmente, e não só nas hostes materialistas -, acarretando a necessidade de reatualização daquela ontologia, com a escolástica medieval e a filosofia cristã várias vezes diminuídas e condenadas desde o início 
da era moderna por Bacon e Descartes, e em cujo propósito de revival da parte de Pe. Vaz, ao percorrer um itinerário todo seu, se pode ver mais um capítulo da rememoração da história do ser: um pouco como Hegel, mas não completamente, visto que Hegel era protestante e chegado ao panteísmo espinosista, ao passo que Vaz não, ele que vinha das hostes da catolicidade e não poderia simplesmente comprar tudo de Hegel pelo valor de face, sendo além do mais brasileiro e às voltas com nossas urgências e realidade, conforme veremos ao fim deste ensaio.

Então, rigorosamente, não estamos diante de um exegeta ou de um historiador, mas de um pensador erudito de horizontes largos e sumamente original que - à diferença do scholar ultraespeciliazado, como eu mostrei em Filosofia no Brasil, para além do conhecimento próprio e da familiaridade com seu objeto e campo de estudos - se caracteriza como todo filósofo genuíno pela originalidade de seu pensamento, a disponibilidade de devassar terras desconhecidas e a capacidade de estranhamento ou de espanto, que os gregos viam na origem da filosofia e a marca do filósofo, ao se ver às voltas inclusive com os objetos mais familiares: este foi o caso de Pe. Vaz em suas investidas na filosofia moderna, que ele conhecia como poucos, e também na filosofia e na realidade brasileiras.

Tudo faz crer que nessas investidas no pensamento moderno, frente a tantas novidades e a tantos novos desafios, Pe. Vaz bem poderia ter falado em um terceiro começo da filosofia, iniciado com Descartes, continuando com Hegel e ainda inconcluso. Mas nunca ele o fez nem o insinuou, prevalecendo ao contrário a disposição de tomar a filosofia moderna como um dos capítulos ou ciclos da filosofia medieval, uma espécie de errância ou deriva, e, com esse intuito, introduzir os tours de force analíticos necessários para vencer tanto seu secularismo quanto seu subjetivismo. Tudo isso com o propósito maior, com a ajuda do hegelianismo e da razão histórica, de restabelecer o liame entre o cristianismo e a modernidade. Liame esse existente, mas abalado, beirando a ruptura, no costado protestante desde os tempos de Lutero e Calvino, ao mesmo tempo em que vira nas hostes católicas nas insurgências teológicas do jansenismo, junto com as querelas religiosas e as perseguições políticas até o fim, os últimos estertores da tradição latina e católica com os resultados que conhecemos, não tendo sobrado pedra (e o que eu estou dizendo é literal, basta visitar a Abadia de Port-Royal nas cercanias de Paris). Contudo, em sua ótica pessoal, tal liame se viu novamente restabelecido, como revival do cristianismo social, que ele testemunhou de perto, em Roma e depois no Brasil, no curso dos anos cinquenta e sessenta com a Nouvelle Theólogie e o Vaticano II.

Este foi, pois, o itinerário de Pe. Vaz em suas investidas no pensamento moderno e na realidade circundante ao se colocar, como pensador independente e criativo que ele sempre foi, frente a duas provas: 
[1] Prova do pensamento, diante de uma conjuntura nova da filosofia europeia, especialmente alemã e francesa: o pensamento moderno com suas novidades e seus pontos cegos, ao procurar Vaz fazer-lhe frente, em busca da resposta para os seus problemas ou lá encontrados em suas análises e seus questionamentos, com as armas e as bagagens da ontologia clássica.

Assim, resumindo, na esteira das distinções ens / essentia e da primazia da existentia da metafísica de Tomás de Aquino, iremos assistir ao filósofo jesuíta cumprindo ao longo de várias décadas um rigoroso programa de pesquisa que resultará na primeira obra que veio a lume nos anos sessenta, Ontologia e história, conforme foi consignado.

O programa prosseguirá com as antropologias filosóficas de 1990-1991, lidas com as lentes de Tomás de Aquino como partes da metafísica ou ontologia clássica e nas quais poderemos ver em seus esquemas, com nossas próprias lentes, como a consciência histórica moderna subsumida nas categorias vazianas do sistema Natureza-Sujeito-Forma, na categoria Sujeito precisamente: uma ontologia moderna, ao fim e ao cabo, mas sem solução de continuidade.

E será concluído com Raízes da modernidade, obra seminal catalogada como Escritos de filosofia VII e publicada em 2002, também já referida. Nada menos que o seu grande legado filosófico e metafísico (Pe. Vaz faleceu em 2002), de cujo escopo, junto com os embates, o leitor poderá fazer uma ideia ao examinar-lhe o sumário, saltando às vistas seus itinerários moderno e medieval, reunidos num só programa: como diz o título, em busca das raízes medievais da modernidade, o itinerário [i] inicia-se, na esteira de Descartes e Kant, pelo embate com as filosofias modernas do sujeito e da consciência, mas não só, dir-se-á, posto que nos levará aos nihilismos metafísico e moral (cap. 1 - Fenomenologia e axiologia da modernidade); [ii] abarca a ontologia teológico-filosófica cristã e tomásica (quase todo o livro, em especial o cap. 15 - Presença e de Tomás de Aquino no horizonte filosófico do século XXI, já citado) e [iii] termina com o confronto com Heidegger sobre o futuro da metafísica: Esquecimento e memória do ser.

[2] Prova da realidade, algo elíptica e pouco desenvolvida em comparação com a prova do pensamento, mas não menos "real" ou efetiva e que poderá ser levada a bom termo, numa leitura em filigrana, com o propósito de devolver-lhe o contexto, brasileiro no caso, referido ao menos em duas oportunidades no depoimento ao livro de Ladusãns que estou seguindo até agora.

Numa primeira, ao aludir Pe. Vaz ao personalismo de Emmanuel Mounier e aos primeiros passos de sua reflexão social e política, levando-o a falar de "amarga decepção": como veremos na sequência, na esteira do golpe militar de 1964, o contexto é o envolvimento do filósofo com a esquerda católica, JUC e AP especificamente, ao aplicar aos meios brasileiros os 
princípios da Nouvelle theólogie do cristianismo social que iriam desaguar no Concílio Vaticano II e nas Encíclicas famosas de João XXIII, Pacem in terris e Mater et magistra. E mais, eu acrescentaria - estou pensando na militância da JUC e da AP, além dos programas do MEB (Movimento de Educação de Base), tendo como grande protagonista Paulo Freire, ao qual Movimento Pe. Vaz se reconhece ligado na entrevista com Marcos Nobre ${ }^{9}$ -, os princípios filosóficos do método pedagógico-político Ver, julgar e agir, estabelecidos por Jacques Maritain, com sua influência extraordinária pelo mundo afora, na extensão do cristianismo social, convertendo-se em quase num novo catecismo. Por fim, ao dar-lhes o remate doutrinal, com sua orientação humanista, os princípios filosóficos da nova antropologia da pessoa humana e propriamente cristã, patrocinada por Mounier, ao propugnar o personalismo, e também por Maritain, ao defender o humanismo integral - ambos em contraposição ao marxismo, um e outro endossados por Pe. Vaz nos escritos do período e, mesmo que sem citá-los, no famoso Documento-base da AP. Vale dizer, o documento fundador da primeira fase da Ação Popular, várias vezes referido, aprovado em 1963 e publicado pela revista Verbum em 1964, como vimos antes. E ainda, ao fechar o quadro: combatido pela alta hierarquia da Igreja Católica ${ }^{10}$, com o filósofo pagando um preço pessoal muito alto, ao ser condenado ao "silêncio obsequioso", saindo da Faculdade de Filosofia de Nova Friburgo e indo parar na UFMG em Belo Horizonte.

Numa segunda oportunidade, em alusão ao tema maior do "Cristianismo e mundo moderno", que sempre lhe foi tão caro - uma questão "vital",

\footnotetext{
${ }^{9}$ NOBRE, M. e REGO, J.M., op. cit., p. 32.

${ }^{10}$ Duas informações contextuais deverão ser fornecidas, cujas considerações se revelarão essenciais para a compreensão do episódio, o qual iria ter um custo pessoal muito alto para Pe. Vaz naquela época, como ressaltado, e iria evidenciar, em seus desdobramentos, carregado de implicações para sua carreira posterior.

A primeira informação incide sobre o Documento-base da AP, sua aprovação no $2^{\circ}$ Congresso e a reação da alta hierarquia da Igreja, como comentado: tudo tendo lugar em 1963, culminando com publicação da Carta Pastoral assinada pelos 7 bispos das circunscrições episcopais da CNBB, ao longo da qual o colegiado máximo acusava a AP de não representar o "autêntico pensamento cristão", condenava a disposição de seus braços universitários (JUC) e secundaristas (JEC) "de fazer aliança com movimentos de ideologia marxista" e instava o comprometimento de seus militantes "em trazer a AP para uma linha genuinamente cristã" (Ver Kornis, verbete $A P$, FGV-CPDOC).

A segunda informação, exigindo ainda esclarecimentos adicionais a serem obtidos em pesquisas ulteriores, incide sobre a publicação do Documento-base: em 1964, pela revista Verbum, da PUC-Rio, como assinalado, precisamente t. XXI, fasc.1-2, mar.-jun., na seção "Notas e comentários" - tudo a seco, como se diz, sem qualquer explicação de sua publicação, nem mesmo no Editorial assinado pelo responsável da revista, Pe. Francisco Leme Lotes. Segundo consta, um conservador notório, que no citado Editorial fala da "ameaça marxista" e, em alusão ao golpe militar, em seu apoio, lhe dá o título "O Brasil escolheu a liberdade". Quer dizer, podemos ver tudo em sua publicação, até mesmo a maquinação da cúpula dos jesuítas e a ação direta do próprio cardeal, Dom Jaime Câmara, um dos signatários da Carta Pastoral e reputado por seu reacionarismo tenaz - menos a decisão de divulgar um documento importante que estava fazendo época, ainda inédito, e homenagear Pe. Vaz, jesuíta como o editor da revista e a direção da PUC.
} 
como vimos ele, no depoimento a Ladusãns, falando sobre si ao se referir a Hegel - e que o motivou a publicar em 1960 na revista Sintese um artigo "programático e militante", segundo ele, e que será seguido de um outro em 1961, aos quais deu o título de "Cristianismo e consciência histórica", e eis os dois artigos de volta, mas com uma angulação diferente: de novo as "decepções" depois da publicação, não digo logo depois, mas três anos mais tarde, e tanto mais graves, conforme suas palavras, que o levaram "pouco a pouco sepultar num passado cada vez mais distante". Precisamente, levaram-no a sepultar não o tema, posto que ele continuou publicando sobre o assunto, como no artigo sobre João XXIII, já referido, em 1963, quando ele era ainda ligado à JUC e à AP, e mesmo depois, num tempo em que já estava afastado ${ }^{11}$, quando veio a lume pela revista Paz e Terra o artigo "Cristianismo e mundo moderno", datado de 1968. Ou seja, se sepultamento houve, foi da militância ou de seu envolvimento com a política, depois que ele saiu de Nova Friburgo, proibido pelo Provincial de ensinar aos jovens seminaristas e até mesmo na PUC-RJ, quando foi para Belo Horizonte, como lembrado, convidado por Arthur Versiani Vellôso, iniciando seu período de magistério na UFMG, de 1965 a 1985. Foi então que lhe foi devolvida a palavra do mestre que ele sempre foi, numa situação ambígua, pois se ele sempre fez o que quis e dizia o que ele pensava no Departamento de Filosofia da UFMG, como ele reconhece, mas houve a punição e a sua suposta condenação ao "silêncio obsequioso". Imposto pela alta hierarquia dos jesuítas, ou seja, pelo Provincial, segundo a versão corrente, senão "auto-imposto", poderíamos conjecturar. Num caso e em outro, sem que se saiba exatamente nem quando começou (certamente se foi imposto, tem algum registro nos arquivos da Companhia: alguém um dia vai esclarecer isso), nem quando ele foi suspenso. Simplesmente, estávamos em plena ditadura, o filósofo só voltou a ensinar numa faculdade católica em 1975 ${ }^{12}$, como vimos acima, na Faculdade Eclesiástica do Rio

${ }^{11} \mathrm{Na}$ entrevista com Marcos Nobre, op. cit., p. 32, ele diz que o afastamento da JUC data de 1964.

${ }^{12}$ A verificar: está-se a falar de vínculo institucional estável ou permanente. Sabe-se que Pe. Vaz de fato continuou atuando, como convidado ou esporadicamente, ao longo dos anos sessenta e início dos anos setenta, no antigo Instituto Central de Filosofia e Teologia, ligado Universidade Católica de Minas Gerais, hoje PUC-MG, onde funcionam atualmente como duas entidades separadas. Desta época vim a saber de Giovanetti que há dois registros atestando o vínculo, ainda que informal: [i] da publicação de um artigo assinado por Vaz no Boletim do Instituto, n. 2, 1968, intitulado "Cultura moderna e suas manifestações ideológicas", cuja cópia me foi passada; [ii] do curso de Filosofia da História, ao que parece na Faculdade de Teologia, em 1972, totalizando 10 aulas, cuja apostila está disponível no Memorial Padre Vaz, hospedado na FAJE, nada impedindo que o filósofo tivesse oferecido mais cursos no intervalo 1968-1972. Sabe-se também que Pe. Vaz voltou a ensinar filosofia na Faculdade de Filosofia dos Jesuítas em São Paulo, quando ela foi transferida de Nova Friburgo para a nova sede localizada na região de Perus, km 26 da Anhanguera: também conhecida como Faculdade de Filosofia Nossa Senhora Medianeira, ela funcionou nesta localidade de 1964-1974 e, em algum momento, antes de 1968, Vaz ofereceu em suas dependências um curso regular de Filosofia da Natureza, conforme relato de pessoa próxima, que lá atuou e teve notícia, havendo ainda 
de Janeiro, e ele só obteve seu habeas corpus isentando-o das suspeições em 1968, depois de quatro anos perseguido pelo regime militar. Foi um pouco depois desta época conturbada, já se encontrando afastado da JUC e distanciado da radicalização política da AP na direção do marxismo-leninismo, quando se converteu na AP-ML, que Pe Vaz, de moto próprio, aprofundou seus questionamentos da esquerda católica e deu início à sua fase conservadora. Em política, bem entendido, mais e mais desconfiado do marxismo, num tempo em que a Igreja Católica e seus setores ditos progressistas, ligados ao cristianismo social, faziam o movimento inverso na direção daquela corrente ideológica, com a Teologia da Libertação. Não Pe Vaz, que seguiu um caminho diferente, sem esconder suas reservas e longe de qualquer militância, até terminar seus dias em total recolhimento, na morada dos padres, junto às dependências da FAJE em Belo Horizonte (Sobre este tópico, ver mais à frente n. 52).

Concluindo o tópico, o filósofo fala da única polêmica em que ele se vira envolvido em vida, nas páginas da revista Vozes, no período 1965-1966, com Alfredo Lage: ligado ao Centro Dom Vital, alinhado com Gustavo Corção, autor de A recusa de ser - A falência do pensamento liberal, publicado em 1971, e insigne representante do pensamento reacionário brasileiro, não tendo poupado Vaz em seus ataques. Especialmente, no artigo "A formação marxista" (Vozes, v. 58, 1964, p. 641-651) e levando Vaz a reagir aos golpes, ao enviar ao editor da revista uma carta pessoal "em defesa das posições tomadas no artigo 'A grande mensagem de João XXIII' [Revista Síntese, v. 5, n. 18, abr./jun. 1963, p. 8-33], devido ao "ataque violento e injusto", datada de 14/07/64. E segundo eu pude apurar, tendo a revista lhe concedido a réplica, com a publicação do artigo da lavra de Pe. Vaz “Cristianismo e história (uma contestação serena) - Resposta a Alfredo Lage", Vozes. v. 59, 1965, p. $817-839 .{ }^{13}$

Ora, haverá ainda uma outra ocasião em que Pe. Vaz se viu envolvido numa polêmica ideológico-política, conforme eu mostrei em Filosofia no Brasil, e desta vez merecendo uma reação contundente, sem as cortesias acadêmicas de conveniência e sem falar em alguém "saudoso", como no caso de Alfredo Lage, ao se referir ao "saudoso" oponente : desta vez contra Antônio Paim, por ocasião da crise da PUC-RJ de 1979, com direito a ataques diretos de Paim a Pe. Vaz em jornais do Rio de Janeiro e de

no Memorial Padre Vaz uma apostila do referido curso, mimeografada, com a identificação da Faculdade e o endereço. Por fim, em 1975, como dito, a Faculdade foi transferida para o Rio de Janeiro, lá permanecendo até 1981, período em que Pe. Vaz foi inclusive Diretor ou, antes, Reitor, na terminologia dos jesuítas.

13 Sobre a resposta de Pe. Vaz a Alfredo Lage, ver VAZ, H.C.L. Acerca de "A formação marxista", Revista Vozes, v. 58, set., 1964, p. 641-651, incluindo nota esclarecedora do Memorial Padre Vaz. Para o perfil político de Alfredo Lage, ver MARTINS, W. “O pensamento reacionário", Estadão, Suplemento Literário, 19/12/1971, onde aparece uma breve menção ao "jesuíta Henrique Lima Vaz". 
São Paulo, tachando-o de filo-comunista, e com o filósofo, ao ser arrastado para a polêmica, depois de muitas vezes provocado, reagindo duramente num artigo publicado na Revista Encontros com a Civilização Brasileira, em 1979, com o título "'Crise' da PUC: Descendo às raízes".

Voltarei a esses pontos importantes da carreira de Pe. Vaz na segunda parte do ensaio, ao me referir ao Vaz político, conquanto brevemente, ao concluir o exame de suas investidas na filosofia brasileira e sua afiliação à tradição ocidental.

Retomando o passo, com o pensador e filósofo no centro das atenções, de olho nos vinte e cinco anos restantes que se passaram do depoimento ao livro de Ladusãns até o fim de sua vida, será preciso considerar a entrevista concedida à revista Cadernos de Filosofia Alemã, que veio a lume em 1997, havendo ainda uma segunda, publicada no livro organizado por Marcos Nobre e José Marcio Rego, já referido e datada de 1999.

Passando para a primeira entrevista, ao precisar a sua vinculação com a tradição filosófica ocidental, o filósofo deixa claro, ao recuperar a etimologia da palavra tradição, que em sua forma verbal a palavra vem de tradere, no sentido que eu já precisei antes e ponto ao qual retorno agora, significando a ação de "entregar" alguma coisa: assim, as gerações em cuja sucessão "vão entregando umas às outras o que vão vivendo, e essa continuidade torna possível para nós rememorar o curso histórico, apreender o passado histórico"14. Trata-se, pois, de fonte e elo, havendo uma dinâmica da tradição ao longo dos séculos, com algumas camadas sendo revolvidas e reatualizadas, outras deixadas para trás e esquecidas. Um pouco como mostra Gadamer em sua hermenêutica filosófica, citado por Pe. Vaz, ao nos falar da "história efeitual", introduzindo o vetor que orienta a tradição para o presente histórico, como resultado e actualização do passado, mas sem perder o elo contínuo que nos liga e traz de volta ao passado como passado. Então, rigorosamente, tradição não tem nada a ver com tradicionalismo e passadismo, vendo Pe. Vaz no tradicionalismo e, por extensão, no culto ao passado, como se lá residisse a idade do ouro, nada menos do que a "mitologização do passado", acrescentando que é "justamente do mito que estamos fugindo"15.

É nesta linha que o ilustre jesuíta reconhece seu duplo alinhamento com a tradição greco-latina e judaico-cristã, a supor a recepção do judaísmo pelo cristianismo, deixada nas entrelinhas, levando-o a afirmar - para além das origens gregas da filosofia e mesmo da centralidade da teologia na filosofia

${ }^{14}$ VAZ, H.C. de Lima. Filosofia e forma de ação [Entrevista]. Cadernos de Filosofia Alemã, 2, p. 86-87.

${ }^{15}$ Idem, p. 88. 
de Platão, que foi quem criou o termo - com uma clareza "mediterrânea", como se dizia no passado, e digo eu agora ao retomar a fórmula:

"o que foi decisivo na evolução cultural do Ocidente foi a recepção pelo cristianismo da filosofia grega; mas, evidentemente, teve de submeter a teologia grega a uma reformulação radical. A teologia, então, já cristã - quer dizer, a teologia fundada não só na conceptualidade filosófica da razão, mas na fé - tornou-se uma espécie de coroa do sistema intelectual e cultural; e a teologia antiga foi colocada num patamar inferior como aquilo que posteriormente chamamos, na tradição, 'metafísica'. Nas diversas acepções, até o racionalismo moderno, essa metafísica toma o título de teologia natural, para se distinguir da teologia da fé. Ao falar aqui de teologia, considero este problema: a filosofia é uma espécie de tradição teológica, primeiro assumida, depois integrada na visão cristã, em seguida, de certo modo, na filosofia moderna"16.

Trata-se do esquema onto-teológico da metafísica clássica, referido acima e repudiado por Heidegger, como foi lembrado, mas que é mantido tenazmente por Pe. Vaz em suas incursões na filosofia antiga e medieval, bem como na filosofia moderna e contemporânea, com a reserva de que em seus escritos em que ele trata da teologia ele não o faz como teólogo, mas como filósofo, e desde logo tomando-a como uma grandeza na história da cultura do Ocidente" ${ }^{\prime 17}$. Grandeza, vem a ser matriz, nem mais nem menos que a ciência, as artes e mesmo a tecnologia nos dias de hoje, e Pe. Vaz sabia muito bem o quanto essa matriz estava combalida na era moderna, depois dos ataques dos materialistas, dos positivistas, dos existencialistas ateus e do próprio Heidegger - donde, numa atitude de resistência e de defesa de suas convicções cristãs, seu firme propósito de relançá-la e de reatualizá-la, buscando aliados na filosofia francesa, como sabemos, nas hostes do personalismo e do maritainismo ${ }^{18}$, mas não só, havendo ainda a Nouvelle theólogie ${ }^{19}$, bem como na filosofia alemã, ao procurar a companhia de Hegel. De Hegel, de quem ele diz não ser exatamente um especialista, mas um autodidata ${ }^{20}$ : desta vez se referindo ao scholar e ao exegeta, fazendo dos estudos em apreço um campo de especialidade, como no caso de Kojève, citado por ele, não sendo este o seu caso, como ele já tinha dito no depoimento a Ladusãns que seu interesse pelo filósofo não era como historiador da filosofia. Agora, o paralelismo é com o exegeta ou o comentador, reenviando-nos à tipologia de Cruz Costa, ao falar dos glosadores com seu fetichismo do texto e da escrita. Contudo, de minha parte, como eu já tinha feito em relação ao historiador, com a reserva no caso do exegeta - reserva da reserva - de que deveremos ver nesta declaração de Pe. Vaz uma afirmação de modéstia intelectual que faz

\footnotetext{
${ }^{16}$ Idem, p. 88-89.

${ }^{17}$ Idem, p. 88.

${ }^{18}$ Idem, p. 92.

${ }^{19}$ Idem, p. 93.

${ }^{20}$ Idem, p. 78.
} 
parte do jogo acadêmico e dos valores cultivados pela academia, e como sempre foi o seu caso, sempre muito polido e reservado no trato com as pessoas e as ideias. Tudo considerado, sem a menor arrogância - e é aí que vem a minha reserva tomada ao avesso -, não é o exegeta, mas o pensador que está em jogo e é com as armas e as bagagens da filosofia e da dialética hegelianas que ele irá fazer frente ao problema todo seu de afrontar os tempos ímpios da filosofia moderna e pensar o cristianismo como religião dos tempos modernos. E precisamente, coisa que ele não diz na entrevista, ao fazê-lo, ele irá introduzir um tour de force e cuidará de trazer Hegel para o seu terreno, posto que, diferentemente do filósofo alemão, que colocava a filosofia acima da religião e da teologia, o filósofo mineiro prefere alinhar-se ao esquema onto-teológico da metafísica tradicional e nele embutir o ferramental da dialética hegeliana e os princípios de sua filosofia.

Concluindo, como a coruja de Minerva, que alça voo ao entardecer e enxerga no escuro, a filosofia é post-festum e, em suas incursões, busca iluminar aquilo que se oferece à meia-luz e trazer para o sol de meio-dia aquilo que estava na darkness e não suspeitávamos. Um pouco foi essa a lição de Hegel, e como ele a de Platão, porém há um limite: a filosofia só chega depois e "o filósofo nunca profetiza, apenas analisa". É o que acontece em seus vaticínios sobre a teologia e a perspectiva do cristianismo nos tempos novos. Com efeito, segundo o filósofo,

"a teologia se apresentou sempre como elemento integrador, era essa sua função. Hoje há um pluralismo teológico muito grande (...), tudo ficou mais complexo. Aparentemente, mesmo para o teólogo, a teologia não tem mais aquela função referencial e integradora. Ela é uma espécie de instrumento para refletir sobre problemas setoriais, um campo sobretudo para o professor de teologia, de estudo de teologia comparativa. Não sei para onde caminhará a evolução do pensamento cristão, tanto protestante, quanto católico, mas acredito que deverá ser criado, ou deverá surgir um paradigma muito mais flexível do que, por exemplo, o paradigma tomista, que aplicava a todo campo do saber o princípio aristotélico da subalternação das ciências. A teologia não pode, por outro lado, tornar-se uma antologia de trechos dos teólogos que têm pouca coisa a ver uns com os outros. Como isto se fará é tarefa dos teólogos. Não me sinto capaz de me pronunciar a respeito" ${ }^{21}$.

Ora, na época em que Vaz concedeu a entrevista, na qual ele alude à "invasão das teologias elaboradas à luz da tradição hindu"22, estava em livre curso a expansão das seitas pentecostais, inclusive no Brasil, tornando a missão do teólogo ainda mais difícil: não bastasse o desafio da realidade, mais e mais fragmentada, haverá ainda o desafio das ciências da religião, ao qual já me referi, tendo como resultante a troca da filosofia pelas ciên-

${ }^{21}$ Idem, p. 93.

${ }^{22}$ Idem, p. 93. 
cias empíricas. O que fazer? Com a palavra os teólogos, diz o jesuíta. Já ao filósofo nada mais resta do que voltar à tradição, retomar a filosofia-teológica de Tomás de Aquino e trazê-la para os tempos modernos, ao submetê-la à prova da nova realidade e ao crivo do logos filosófico, ou seja, da razão universal, como ele fará em seus artigos consagrados ao doutor angélico, como o que vimos citando, e em seu livro Raízes da modernidade.

Passo agora para a segunda entrevista, concedida ao livro Conversando com filósofos brasileiros, e eu serei breve, em parte por não querer ser repetitivo, em parte por seu escopo ser antes de tudo o Brasil, que será examinado mais à frente.

Sobre o alinhamento de Pe. Vaz com a tradição filosófica e seu papel como pensador com luz própria e independente, creio que três ordens de considerações nos ajudarão a dar o remate de seu perfil intelectual esboçado até aqui:

[1] a formação recebida na Faculdade de Filosofia em Nova Friburgo: "padrão tradicional" das faculdades da Companhia de Jesus, "aristotélico-tomista" ${ }^{23}$, várias vezes ressaltada nas páginas anteriores, devendo ser acrescentado a influência de Agostinho, "que ele conheci[a] ainda estudante de filosofia e que João Paulo II repete na sua encíclica Fides et Ratio: 'crê para entenderes e entende para creres'"'24;

[2] as novas afinidades eletivas somadas e adensadas ao longo do tempo: numa vertente, a sua aproximação da obra de Hegel, retomada e aprofundada nos tempos em que lecionou na UFMG, com destaque para os cursos de pós-graduação iniciados em 1974, levando-o a percorrer quase todo o universo do sistema hegeliano - e tanta mais tenaz e profunda a aproximação que a resultante das investidas foi a dilatação de seus "horizontes filosóficos, ainda circunscritos ao universo aristotélico-tomista", e a incorporação do método dialético em suas incursões filosóficas "na direção dos problemas da história e da sociedade (...) e sobretudo na direção do intento hegeliano que mais [o] seduziu: a releitura da metafísica clássica nos quadros da Ciência da Lógica"25; noutra vertente, a sua aproximação da filosofia francesa, havendo mais de um nome, como já foi assinalado, ao se considerarem as afinidades eletivas: a começar por Jacques Maritain, com um grande raio de influência, atestado pelos Institutos consagrados à difusão de seu pensamento pelo mundo a fora, inclusive no Brasil, em São Paulo, com Franco Montoro na linha de frente, e no próprio Vaticano; passando por Teilhard de Chardin, renomado paleontólogo jesuíta, por quem Vaz tinha enorme apreço, porém algo distante de suas preocupações como filósofo ${ }^{26}$; e terminando a lista com Emmanuel Mounier e Henri Bergson

\footnotetext{
${ }^{23}$ NOBRE, M. \& REGO, J.M., op. cit., p. 29.

${ }^{24}$ Idem, p. 41.

${ }^{25}$ Idem, p. 30.

${ }^{26}$ Idem, p. 33-34.
} 
- Bergson, que segundo Pe. Vaz estava certo ao constatar o gap entre "a produção material da sociedade e seu universo simbólico" 27 , exigindo que alguma coisa devesse ser feita, poderíamos dizer; Emmanuel Mounier, mais especialmente, "cujos livros eram também uma leitura quase obrigatória" e cuja presença em sua vida e de outros tantos católicos progressistas foi um verdadeiro "modelo", e antes de mais nada porque, como ninguém, "ele soube unir reflexão e ação sob inspiração de uma doutrina ao mesmo tempo comunitária e personalista e aqui residia, parece-me, o segredo da atração por ele exercida sobre a juventude universitária cristã ${ }^{\prime 28}$.

[3] a agenda filosófica tardia de Pe. Vaz ou do Vaz maduro, levada a cabo como agenda pessoal ou própria: engloba em seus eixos principais a metafísica, a ética e a antropologia filosófica, conforme mostram as coleções da Loyola que hospedam suas obras, levando-o a precisar a orientação mais e mais hegeliana de seu pensamento a partir dos anos setenta [i] no tocante à metafísica clássica, que será algo alterada na direção do hegelianismo, ao passar suas categorias centrais pelo crivo da Ciência da lógica, como vimos ${ }^{29}$, sem esquecer que antes dela veio a Fenomenologia do espirito, da qual ele se ocupou em seus cursos, tradução, artigos e em livro (póstumo), assim como em outras obras, ao instaurar a centralidade do saber absoluto, aqui $[F E]$ como resultado, lá $[C d L]$ como ponto de partida; [ii] no tocante à ética, mais além da ética aristotélica das virtudes, do sumo bem platônico e da Sittlichkeit hegeliana [Eticidade, distinguida da Moralidade], os desafios específicos da moral cristã ao ser trazida para o contexto dos tempos modernos: desta feita, ao fazer frente às tendências hedonistas, relativistas e utilitaristas que prevalecem nos tempos novos, resultando no nihilismo moral - expressão que o filósofo não emprega na entrevista, mas que está em jogo - e, no mesmo passo, levando-o a contrapor à ação corrosiva daquelas tendências o ethos evangélico instaurado e propagado por Jesus, tendo por modelo de vida santa São Francisco de Assis e Tereza de Calcutáio; [iii] no tocante à antropologia filosófica, cujo percurso na história da filosofia começa com Sócrates, que foi quem começou tudo, passa por Agostinho, Tomás de Aquino e a antropologia tripartida, chega à época contemporânea com Sartre, Scheler e Gehlen, e no mesmo passo passa a receber ataques de todos os lados, com Heidegger e Foucault falando de antropologismos, sono antropológico e coisas parecidas, o filósofo irá tomar um outro caminho - um caminho fazendo

\footnotetext{
${ }^{27}$ Idem, p. 37.

${ }^{28}$ Idem, p. 34; o contraste no plano filosófico é com Maritain, também muito influente com seu método de Ver, julgar e agir, já referido, mas de quem Vaz não esconde uma certa reserva, dizendo que para ele e seu entorno, ao longo da "década de 60, o aspecto discutível do pensamento político maritaineano era a ideia de uma nova sociedade vitalmente cristã, uma nouvelle chrétienté, mas que guardava uma imagem até certo ponto idealizada da cristandade medieval", idem, p. 33.

${ }^{29}$ Idem, p. 30.

${ }^{30}$ Idem, p. 40
} 
pendant à ética e à metafísica, ao mesmo tempo que as solicita e lhes abre passagem, cuja formulação Pe. Vaz fornece na seguinte passagem, depois de interpelado para esclarecer se teria havido uma guinada conceitual em sua obra consagrada à Ontologia e história, no capítulo final, e ele responde se reportando às Antropologias filosóficas publicadas até então:

“De Ontologia e história [1968] a Antropologia filosófica [1991 e 1992] há um bom caminho andado. Para mim o clima intelectual havia mudado e o diálogo com Hegel tornara-se prioritário. Na Antropologia filosófica a noção de consciência cede lugar à noção mais abrangente do Eu (em sentido fenomenológico-dialético) enquanto momento mediador entre o que nos é dado como natureza e o que é por nós significado como forma. Em outras palavras, o Eu opera no ser humano a passagem dialética entre o que simplesmente é e a sua auto-expressão, ou seja, a significação com que ele se anuncia na sua identidade propriamente humana, para falar como Ricoeur. O conceito de expressividade, cuja origem se deve a J. G. Herder e foi retomado por Hegel e recentemente posto em circulação por Charles Taylor, é o conceito propriamente fundacional da Antropologia filosófica (ver vol. 1, pp. 162-167). A ideia de consciência reaparece aqui como uma das variantes constitutivas da categoria do espírito (ibid., pp. 211-2), integrada na dialética mais ampla da auto-expressão do ser humano como espírito" ${ }^{\prime 31}$.

A lembrar que, além das categorias do sistema ou do discurso acima referidas, Natureza-Sujeito-Forma, haverá as categorias de estrutura: Corpo Próprio-Psiquismo-Espírito, abarcando aquilo que é ou manifesta-se em face da universalidade do ser, e categorias de relação: Objetividade-Intersubjetividade e Transcendência, pivotadas pela nossa relação com o mundo, o outro e o absoluto = Deus ou o Espírito.

Donde a consumação da visão da filosofia de Pe. Vaz: uma visão clássica, para não dizer tradicionalista, termo que ele repudia, e além do mais fundacionista, como ele disse da antropologia filosófica, conforme acabamos de ver, e como ele dirá mais uma vez ao falar de toda a sua filosofia: da antropologia, passando pela ética, até a metafísica, caracterizada (a visão) pela busca de princípios que uma vez encontrados serão erigidos como fundamentos, e, como tal, ao largo dos verbalismos da filosofia da suspeita e das derivas pós-modernas. Escreve Vaz:

“Em outras palavras, só entendo a filosofia como 'fundacionista', para usar um termo hoje em moda. Nesse sentido, os conceitos representativos da minha posição filosófica, ao longo da sua evolução, são conceitos 'fundacionais', se assim posso falar. Eis alguns: inicialmente o conceito de 'ato de existir' (esse) recebido de Tomás de Aquino e de alguns de seus comentadores recentes (E. Gilson e outros), e que para mim é a pedra fundamental da Metafísica, à qual tenho voltado em textos recentes. Em seguida citarei o conceito fundamental da Antropologia filosófica, ou seja, o 'ato de existir' do

${ }^{31}$ Idem, p. 34. 
ser humano enquanto capaz de significar-se a si mesmo ou do ser humano como expressividade. A Metafísica e a Antropologia filosófica abriram-me o caminho para a Ética, disciplina que eu tenho ensinado nos últimos anos. O conceito fundamental, recebido de Platão e Aristóteles, é o conceito de Bem, que se apresenta como conceito metafísico, sendo um conceito transcendental coextensivo com o ser, e como conceito antropológico, definido como Fim e estrutura teleológica do ser humano como ser que se autodetermina para o Bem. Esses dois conceitos fundamentais, antropológico (Eu como expressividade) e ético (Bem), guiaram-me na relação dos dois textos, Antropologia filosófica (2 vols.) e Introdução à ética filosófica (2 vols.), que publiquei recentemente. Penso que os conceitos que eu chamo 'fundacionais', presentes desde o início no núcleo básico das ideias filosóficas nas quais fui formado, foram sendo explicitados e adquirindo uma estrutura formal mais definida ao longo do meu magistério e do trabalho de preparação dos meus cursos. Aqui está realmente o roteiro da formação das minhas ideias filosóficas fundamentais" ${ }^{\prime 32}$.

Compreende-se então que o filósofo poderá até falar de flexibilização de paradigmas e de recalibragens do aparato conceitual, como ao se referir ao paradigma teológico-metafísico de Tomás de Aquino que ele diz seguir em sua empresa filosófica e, no mesmo passo, expressar sua tremenda resistência aos modismos filosóficos, como o pós-modernismo francês. E ainda, sua enorme desconfiança frente às sucessivas guinadas da filosofia contemporânea, como o linguistic, o pragmatic e o hemeneutic turns, levando uns a falar de filosofia pós-metafísica, outros de meta-linguagem e pragmática filosófica. Para Pe. Vaz nada disso, a metafísica continua e vai continuar - o exemplo é o tomismo ou, antes, o paradigma tomásico, termo que ele prefere - e como bem o mostram, aliás, as recaídas recentes da filosofia da mente e da filosofia analítica na metafísica, poderíamos acrescentar. Para ele nada disso, não está em jogo refundar a metafísica ou propugnar uma nova ontologia, mas retomar e restabelecer a agenda da metafísica ou ontologia clássica, tomando as figuras do sujeito, da consciência e da alteridade, com suas modernidades, como expedientes ou instâncias da rememoração, histórico-metafísicas, no caso - e, desde logo, cabendo ao verdadeiro filósofo apenas seguir as vias abertas pelo paradigma teológico-metafísico de Tomás de Aquino, introduzir o tour de force da exigência de sistema propugnado por Suarez e remodelado pelo idealismo alemão, especialmente Hegel, e levar a cabo, ao reatualizá-la, a tarefa da filosofia.

Ora, a tarefa da filosofia, como ele afirma no ensaio "Filosofia e cultura: perspectiva histórica", consiste justamente, conforme lembra um dos entrevistadores ao se lhe referir, em "unir dialeticamente Liberdade e Razão (...)". Solicitado para esclarecer a afirmação, ele dirá ao refazer o fraseado com a pergunta filosófica que pede uma resposta: "Como encontrar um

${ }^{32}$ Idem, p. 36-37. 
lugar para a liberdade no universo da razão?" e, mais ainda, de uma razão cuja atividade se define pelos "dois predicados da necessidade e da universalidade", ao passo que a liberdade parece se dar melhor ali onde impera a contingência e o domínio do indivíduo e do aberto? Escreve Pe. Vaz:

"Eis o desafio maior e, de certo modo, a tarefa única da filosofia, pois trata-se de um problema que tem repercussões imediatas e decisivas na antropologia filosófica, na ética, na política, nas concepções, em suma, do universo, do ser humano e de Deus. Para o Cristianismo, esse tornou-se, a partir sobretudo de Santo Agostinho, um problema fundamental para a reflexão teológica, pois a fé se apresenta como uma 'geratriz de razão', no dizer de E. Gilson: Crede ut intelligas. Ele encontrou uma solução genial em Santo Tomás de Aquino, no qual nos inspiramos na nossa Antropologia filosófica, vol. 1. Pensar a liberdade foi, talvez, o leitmotiv maior do filosofar hegeliano, como procuramos mostrar no capítulo sobre a Ética de Hegel, na Introdução à Ética filosófica I (pp. 371-400). Assim, penso estar explicada a afirmação citada na pergunta" ${ }^{\prime 33}$.

Então, concluindo, se eu fosse perguntado qual é o melhor termo ou a expressão mais adequada que poderíamos usar como etiqueta para designar o pensamento e a obra de Pe. Vaz, eu diria que ele é antes de tudo um tomista ou mesmo um tomásico, termo que ele inclusive prefere. Porém, ao falar do paradigma tomásico, como Vaz deixa claro na entrevista concedida ao Cadernos de Filosofia Alemã, várias vezes referida, ele tem em mente "um paradigma muito mais flexível do que, por exemplo, o paradigma tomista, que aplicava a todo campo do saber o princípio aristotélico da subalternação das ciências" ${ }^{\prime 3}$. Não se trata de nada disso, segundo o ouro-pretano ilustre. O novo paradigma tomista que ele procura, não é o tradicional, pelas razões já expostas, nem o neotomista, por tudo que ela carrega, desde o desejo de revival da cristandade medieval de um Maritain, até os alinhamentos com as alas mais à direita da Ação Católica francesa. Trata-se, ao invés, de um novo paradigma tomista flexibilizado pela dialética, com suas duas ascendências maiores, Platão e Hegel. Então é isso, está-se diante de uma trindade, composta por Platão, Tomás de Aquino e Hegel, com Tomás de Aquino ao centro, ladeado pelo grego e pelo moderno. Contudo, Vaz não era um platônico, nem era o caso de recuar Tomás de Aquino até ele e à dialética do sofista, da mesma forma que não era um hegeliano nem queria passar para a história da filosofia brasileira como hegeliano, mas como um tomista ou um tomásico. Porém, se não estava em jogo andar para trás e retrogradar a história da filosofia até Platão, mas andar para a frente e enfrentar o desafio da modernidade, levando-nos a Hegel e, com ele, fazer a viagem de volta, ao rememorar e reatualizar tudo aquilo que foi recalcado e conjurado pela tradição desbussolada, como a tradição e a filosofia modernas. De resto, uma filosofia que, na esteira da

\footnotetext{
${ }^{33}$ Idem, p. 43-44.

${ }^{34}$ VAZ, H.C. de Lima. A filosofia como forma de ação [Entrevista], op. cit., p. 93.
} 
metafísica da subjetividade, recalcou o Absoluto e o Transcendente, como aliás Hegel, ao suprassumi-los na imanência do Espírito e das coisas deste mundo. Ora, este não é caso do filósofo jesuíta, mas Hegel foi grande e ele tinha a dialética. Então, tudo considerado, haveria ainda uma segunda etiqueta: além de tomista ou tomásico, Pe Vaz é um tomista-hegelianizado, não exatamente um hegeliano-tomista, ou talvez melhor ainda, se não encompridasse tanto, um tomista-platônico-hegelianizado.

\section{O Brasil, a Filosofia e a Tradição Ocidental}

Terminada a exposição do quadro geral do alinhamento de Pe. Vaz com a tradição filosófica ocidental e cristã, como ele mesmo enfatiza, ao longo da qual pudemos evidenciar as provas a que ele submeteu suas incursões em diferentes planos da filosofia, atestando a fecundidade de suas contribuições como pensador independente - prova de pensamento e prova de realidade -, darei um passo a mais e focalizarei até o final do ensaio seus embates e envolvimentos com a filosofia no/do Brasil e a realidade brasileira.

Estes embates e envolvimentos transcorreram ao longo de vinte e cinco anos, com destaque - em linha cronológica - para os artigos "O pensamento filosófico no Brasil de hoje", 1961; "Consciência e realidade nacional", 1962; "Filosofia no Brasil, hoje", 1978; e "O problema da filosofia no Brasil", 1984.

Ao restituir as grandes linhas do enquadramento dessas incursões vazianas na filosofia e realidade brasileiras, longe de mim de propor sumarizar esses artigos, posto que redundante e sem sentido, estando todos à mão no Memorial Padre Vaz, mas realizar outra coisa: restituir o alinhamento da filosofia brasileira com a tradição filosófica, nada mais, lembrando que já fiz um exame minucioso desses materiais no meu livro Filosofia no Brasil: Legados e perspectivas.

Deste conjunto dos quatro estudos do filósofo jesuíta, serei brevíssimo acerca do artigo de 1962, consagrado à obra de Álvaro Vieira Pinto com igual título, ao longo do qual Vaz faz uma duríssima avaliação da obra ambiciosa do pensador isebiano, e de fato bem mais severa e contundente do que o artigo de Gerard Lebrun publicado no mesmo na Revista Brasiliense, intitulado "A realidade nacional e seus equívocos": especificamente, no caso de Pe. Vaz - ao pressupor o enquadramento do pensamento do isebiano numa matriz intelectual não tão nacional assim, mas europeia, com suas interlocuções com o existencialismo de Sartre e o materialismo de Marx -, elencando suas falhas metodológicas (A.V. Pinto parafraseia o tempo todo e não cita ninguém), seus déficits teórico-conceituais ao operar com as ideologias e concepções de mundo e, sobretudo, as graves inconsis- 
tências filosóficas ao se dar por satisfeito com a consciência reflexa em sua dupla proveniência do marxismo ortodoxo e do materialismo naturalista.

Passando para o artigo publicado em 1961 na Revista Portuguesa de Filosofia - revista de extração jesuítica, como foi ressaltado, e em cujas páginas se deu o début do filósofo nesse terreno tão nosso e ao mesmo tempo tão esquecido, certamente ao atender uma encomenda - lembro que Pe. Vaz tinha grande apreço pelo paper, consignando que ele the deu muito trabalho na prospecção das fontes, quase inexistentes, num tempo em que a produção filosófica brasileira era pobre e rala, e reconhecendo em seu embate seus alinhamentos com as análises de Cruz Costa e Leonel Franca. Ora, deixando à parte a lista generosa de nomes de candidatos a filósofos nacionais, em grande parte esquecidos depois de sessenta anos, conserva ainda atualidade e é de grande interesse o enquadramento da filosofia nacional ou feita no Brasil em sua matriz europeia, alemã e francesa em sua maioria, e, em sua extensão, o alinhamento com a tradição filosófica ocidental e cristã, como será o caso de muitos repertoriados: de universidades públicas, uns (Pe. Penido, UFRJ), e de privadas, outros (Pe. Leonel Franca, PUC-RJ).

Assim, ao terminar o cômputo das instituições universitárias de uma maneira ou de outra com a missão de difundir a filosofia em nosso país, o articulista não hesitará em carregar na retórica em defesa da difusão da filosofia cristã em nossos meios e, mais ainda, o alinhamento do nosso país com a civilização ocidental e cristã. Escreve Pe. Vaz a esse respeito:

“Se a reflexão filosófica de nível universitário, assume agora [anos quarenta] uma importância decisiva no processo cultural brasileiro, o pensamento cristão deve surgir como um componente essencial de fundamental desse esforço, que se dirige a uma interpretação do nosso mais autêntico ser e a um empenho consciente na linha de nosso verdadeiro destino. Com efeito, a nossa proveniência histórica confere irrevogavelmente uma substância cristã à nossa civilização. E na hora em que a cultura avança entre nós para a maturidade das criações originais, é historicamente imperativo que no plano dessas criações venha a exprimir-se também a nossa essência cristã ${ }^{\prime 35}$.

Paralelamente, ao elencar as principais orientações ou tendências da filosofia institucionalizada brasileira, considerando os campos disciplinares, seus principais representantes e seus alinhamentos com a matriz europeia, o ilustre estudioso destacará no campo da metafísica o alinhamento da maioria dos filósofos nacionais com a metafísica clássica, como no caso de Renato Czerna, e mais ainda sua vertente cristã, em pleno revival na Europa, na esteira de Maritain, Blondel e Sciacca: especialmente Maritain e o neotomismo, como no caso de Alceu Amoroso Lima ${ }^{36}$. E para terminar

\footnotetext{
${ }^{35}$ VAZ, H.C. de Lima. "O pensamento filosófico no Brasil de hoje", Revista Portuguesa de Filosofia, v. 37, 1961, p. 242.

${ }^{36}$ Ibidem, p. 264-265.
} 
essas considerações, ao retomar o mesmo tom de exaltação apologética, Pe. Vaz procederá à defesa incondicional do enquadramento da filosofia e da cultura brasileiras na tradição ocidental, ao colocar na extensão desta tradição as Américas, incluindo o Brasil, e desde logo autorizando-nos a tomar os três continentes em bloco, como partes de uma mesma civilização. Escreve Vaz:

"É, decididamente, na direção da voz que nos fala pela sabedoria europeia [o contexto são interlocuções ocorridas no Congresso Brasileiro de Filosofia ocorrido dois anos antes em São Paulo, nas quais "o sentido da reflexão filosófica em terras americanas" foi abordado por dois congressistas] que os pensadores americanos devem, a nosso ver, inclinar a rota da sua reflexão. Mas é que Europa e América formam hoje o todo indissociado e homogêneo da civilização ocidental, que mergulha na mesma tradição, vive os mesmos valores ocidentais, e lança à vida a mesma problemática. A originalidade da cultura americana será um inexpressivo mosaico de ideias europeias se não for a reelaboração vital e o repensamento em perspectivas novas destas ideias, de tal sorte que a sua vida pulse tão autêntica e vigorosa aqui como lá, porque circulando num solo de comum cultura. A América não é mais a franja cultural da Europa. Mas é porque a Europa não é mais a detentora privilegiada da cultura que ela criou. Desde que a vida cultural americana (no nosso caso a brasileira) atingiu a maturidade da autoconsciência e possui seus órgãos normais de expressão nas grandes Universidades, o problema da transculturação perde a sensibilidade sentimental que comunicam os nacionalismos irritados, para formular-se nos termos do fenômeno saudável de circulação transnacional de valores ideais, que são universais porque são humanos" ${ }^{37}$.

Em suma é isso: alinhamento, sim, e circulação transnacional das ideias, sim, porque tudo veio de Platão e do Mediterrâneo, tendo chegado até nós, nesta parte do hemisfério; mas subserviência e mitificação frente a tudo que vem da Europa e dos centros europeus, não, tudo devendo, daqui e de lá, passar pelo crivo da razão e se pôr à prova de uma atitude crítica e independente.

Por sua vez, no artigo publicado em 1978 nos Cadernos SEAF o tom apologético muda e dá lugar a uma linguagem menos reverencial e mais comedida. Agora passa a prevalecer a tentativa de reconstruir a chegada e a difusão da filosofia nas Américas com a ajuda do ferramental da dialética hegeliana, bem como das lentes do platonismo e da tradição filosófica, levando-o a falar: com Hegel, do surgimento da filosofia em razão do colapso do mito e da ruptura da unidade da experiência imediata; com Platão e Aristóteles, do espanto ou estranhamento que está associado ao verdadeiro filosofar e leva ao questionamento filosófico, a igual distância da "familiaridade" do erudito com suas matérias e do próprio senso comum; com Platão e Kant, do tribunal da razão - ou, antes, do logos,

${ }^{37}$ Ibidem, p. 271-272.

Síntese, Belo Horizonte, v. 48, n. 150, p. 205-247, Jan./Abr., 2021 
embora Platão nunca tenha falado de um tal tribunal, mas do exame das ideias e opiniões -, devendo as mesmas passar por um escrutínio crítico antes de serem aceitas e entrarem em circulação, ao se submeterem a uma "crise", como diziam os gregos (krinein = criticar). Como se sabe, expedientes e atitudes que estão na origem da filosofia como civilização do $\log o s$ e em toda sua extensão centrada no $\log o s$, conforme pretendem Sócrates e Platão - e de resto, como será o caso de toda a filosofia grega, bem como medieval e moderna, desautorizando a crítica ao logocentrismo por Derrida e seus discípulos, hoje uma legião.

Continuando, antes de examinar a situação da filosofia no Brasil, da Colônia aos nossos dias, Pe. Vaz irá formular um topos instigante de sua reflexão pessoal e que será retomado no artigo de sua lavra publicado em 1984, já citado, ao tratar dos dois começos históricos da filosofia: [i] o começo grego, na esteira da passagem do mito ao logos, cujo ápice se dará entre os séculos V e III a.C e tendo como grandes protagonistas a trinca Sócrates, Platão e Aristóteles; [ii] o começo medieval latino, na esteira da simbiose da filosofia e da teologia ou entre a razão e a fé, protagonizada por Agostinho e Tomás de Aquino, e dando azo a uma nova civilização filosófica ou, talvez melhor ainda, a uma segunda vertente da tradição filosófica: a tradição judaico-cristã, e antes de tudo cristã, que será acomodada à tradição greco-romana ${ }^{38}$.

Ao passar para as Américas, com o Brasil na linha de frente, Pe. Vaz falará de um "terceiro tipo de experiência histórica", e não exatamente de um "terceiro começo", como poderíamos nos sentir autorizados, como no caso da terceira origem moderna, discutida antes, e se não o fez é porque se tratava não de um começo, mas de um "recomeço": justamente, o recomeço da experiência medieval latina em terras americanas, nas pegadas da segunda escolástica, que para cá foi transplantada da Ibéria com as armas e as bagagens de tradições e instituições inteiras - dos colégios e seminários aos manuais escolares e títulos acadêmicos, com a Companhia de Jesus na linha de frente. Estou comentando essas coisas, ao retomar uma linha de reflexão já desenvolvida em meu livro Filosofia no Brasil, ao longo do qual eu cito largamente Pe. Vaz, ao me voltar para esse longo período de nossa história, e a quem agora volto mais uma vez, forçando um pouco a letra do texto, mas com a preocupação de não adulterar o que está consignado nas passagens referenciadas e me manter fiel ao seu espírito. E, antes de tudo, ao consignar que a via seguida nestas paragens, à diferença do que teve lugar nos dois começos europeus, o grego e o latino, não foi o da assimilação dos povos e das culturas pré-existentes: em vez, elas foram silenciadas ou dizimadas, sou eu que estou afirmando, e o caminho seguido, como notou Pe. Vaz, foi o da réplica e da transplantação

${ }^{38}$ VAZ, H.C. de Lima. "Filosofia no Brasil hoje", Cadernos SEAF, ano 1, n. 1978, p. 11. 
num movimento de mão única, de sorte que, rigorosamente, não havia por aqui e nem fazia sentido em falar de uma filosofia brasileira no período colonial - e isto pela simples razão de que tudo aqui existia foi importado e transplantado da Europa para cá, não sendo diferente o caso das ideias.

Terminando essa reconstituição, o filósofo acrescentará que o século XIX brasileiro continua com a mesma experiência iniciada na Colônia, de modo que nada muda nesse movimento de mão única do fluxo das ideias da Europa para esta parte do hemisfério, mas com duas diferenças: a diferença da troca da influência portuguesa e ibérica por outras influências, como a francesa, a inglesa e a alemã, que ele aponta; a diferença que ele não aponta, por ter tomado tudo em bloco e deixado de lado o contraste da atitude do missionário jesuíta e a do diletante autodidata que se acerca da filosofia não com a missão da educação das mentes e da conquista das almas, mas como ornamento da formação liberal (direito p. ex.) e, ainda, como mera curiosidade intelectual, fascinado pelos modismos das ideias e as etiquetas dos livros importados da Europa ${ }^{39}$.

A se acreditar em nosso filósofo, que em seus estudos enfatizou a filosofia institucional acadêmica, e, como tal, lastreada pela tradição europeia em suas vertentes grega e latina, o mesmo ocorrendo na Europa e nas Américas, tal situação de subserviência só será alterada no curso do século XX: precisamente, depois dos anos trinta, na esteira da fundação das primeiras universidades brasileiras, com a criação das primeiras faculdades de humanidades e dos primeiros departamentos - antes chamados "seções" - de filosofia. Trata-se de um momento único da história brasileira, quando a questão do nacional passou a ocupar o primeiro plano, consumado com a passagem de um país de cultura rural e arcaica para um país de cultura urbana e moderna, levando os nossos escritores e intelectuais, nas pegadas da Semana de Arte Moderna, a perguntarem pelo caráter do brasileiro e da cultura brasileira ${ }^{40}$.

Ao chegar a esse ponto, assim como já tinha acontecido nos Estados Unidos no fim do século XIX, quando os norte-americanos anunciaram aos quatro ventos que eles tinham suas filosofias e escolas de pensamento, como o pragmatismo e o instrumentalismo, coisa que não tinha acontecido com o Brasil $^{41}$, passa a fazer sentido a pergunta pela possibilidade de uma filosofia genuinamente brasileira, com autoestima, sem o complexo de vira-latas e com agenda própria. Ao que parece, sim, tal seria a resposta, pois Vaz reconhece que já atingimos maturidade intelectual e a filosofia goza em nossos meios tanto de solidez institucional quanto de enraizamento histórico e cultural. Este ponto, porém, não é desenvolvido a contento, tendo o filósofo trocado seu exame pelas realizações da filosofia ao longo do século $X X$, com a ajuda de uma engenhosa tópica dos lugares do filosofar

\footnotetext{
${ }^{39}$ Idem, p. 12-14.

${ }^{40}$ Idem, p. 14

41 Idem, p. 13.
} 
na cultura brasileira, e não só lugar institucional, diga-se (lugar sócio-institucional do ensino e da difusão da filosofia, lugar sócio-ideológico da crítica e da discussão das ideias, lugar axiológico do questionamento dos valores e da cultura, lugar teleológico da reflexão sobre os fins da cultura e da sociedade), deixando sem formular e responder às perguntas que não querem calar: $\mathrm{O}$ que entender por filosofia genuinamente brasileira? Uma filosofia nacional ou nacionalista? Ou será uma filosofia universal e brasileira? Precisemos: esta possiblidade ( $\left.2^{\underline{a}}\right)$ em analogia com a filosofia francesa e a alemã, que são filosofia da França e dos franceses, bem como filosofia da Alemanha e dos alemães, com suas particularidades, e ao mesmo tempo exemplares da filosofia universal, como foi a filosofia grega um dia e foi também o caso da filosofia medieval num vasto período em que não existia estado-nação ainda. Minha suspeita é que é bem na segunda disjuntiva que iremos encontrar Pe. Vaz, que no artigo da Revista Portuguesa de Filosofia sugere que a filosofia é universal, porque relativa não a este ou a aquele povo, esta ou a aquela língua, mas a toda a humanidade, que é a mesma por toda a parte e ao mesmo tempo diferente.

Por fim, o artigo publicado pela revista Síntese em 1984, e, portanto, seis anos depois do da SEAF (de fato menos, posto que oriundo de uma conferência proferida em 1981 na UFMG, como foi lembrado), dando-lhe continuidade em suas linhas argumentativas fundamentais e ao mesmo tempo apresentando novidades e inflexões em seu escopo e propósito de pensar a filosofia no/do Brasil.

Do conjunto do artigo, com 14 páginas, salto - não sem lamentar - a nova retomada que Pe. Vaz faz na primeira parte, ao voltar ao artigo da SEAF, do velho tópico do logos grego, acrescentando, porém, novos elos na dialética das ideias: assim, ao distinguir a sabedoria gnômica e a sabedoria filosófica; os dois espaços semânticos do logos e suas duas perguntas axiais (O que é o ser? O que é o pensar?, com Parmênides afirmando que é uma coisa só e Vaz dizendo que o logos distingue para unir ou reunir); o logos como ordem das razões (razões universais e necessárias, em suma) e a instauração da filosofia universal, na esteira da razão universal e conhecido depois de Aristóteles como lógos apodeiktikós ${ }^{42}$. Salto tudo isso para concluir, com Pe. Vaz, que a civilização ocidental nascida da antiguidade clássica, identificada com a civilização filosófica, num tempo em que a filosofia era a ciência sinóptica e abarcava tudo, à diferença do que acontecerá dois milênios mais tarde, é a civilização do $\log o s$ ou da razão ${ }^{43}$.

Esclarecido esse ponto, passo para o Brasil. Novamente, estamos diante da retomada do artigo de 1978, não se tratando, no entanto, de meras repetições ou paráfrases, como logo o leitor irá notar.

\footnotetext{
${ }^{42}$ VAZ, H.C. de Lima. "O problema da filosofia no Brasil", Sintese, n. 30, 1984, p. 13.

${ }^{43}$ Idem, p. 18.
} 
A começar pelo topos do Brasil Colônia como parte integrante da Civilização Ocidental, integrado no ciclo da expansão colonial das potências europeias, primeiro entrepostos e feitorias, depois colônias de povoamento, levando-o a considerar a colonização como um dado histórico normal, existente desde sempre, como no caso das colônias gregas no norte da África e na Sicília: num primeiro momento, no caso dos gregos, sem se misturarem às culturas autóctones, criando nas colônias réplicas da cidade-mãe; num segundo momento, em interação e numa relação de assimilação, como ocorrerá, no rastro dos gregos, numa escala bem maior, com os romanos.

Ora, este nunca foi o caso do Brasil, como nós sabemos, com os ameríndios perseguidos, caçados como escravos, segregados e relegados nos cafundós da sociedade colonial, senão simplesmente dizimados, às pencas, chegando no fim da era colonial a vários milhões de mortos, um verdadeiro genocídio - coisa que Pe. Vaz não considera ao retomar o topos hegeliano da cisão da unidade imediata, gerando a crise de identidade e a exigência da filosofia, como necessidade interna e viva da cultura, como no caso grego $^{44}$. Contudo, nunca foi o caso aqui: nem com os nativos, cuja unidade comunal foi destruída pelo colonizador branco alienígena, até mesmo nas reduções dos jesuítas, com os povos separados de seu habitat e tutelados pelos religiosos, nem com os negros africanos, quando foi implantado o escravismo colonial nestas paragens com todo seu cortejo de crueldades, ao serem arrancados da África e aqui mais uma vez separados, desfazendo famílias e resultando na maior diáspora dos tempos modernos, como todos nós sabemos; porém, nem um caso nem outro foram tocados e desenvolvidos por Pe. Vaz. Tanto mais essencial o lapso que data desta época - a contrapelo da implantação da colônia de povoamento e sua unidade, desafiando a unidade imediata hegeliana que se desintegrará por sua dinâmica interna - a criação de uma sociedade desde o início partida e excludente. Uma sociedade que logo tratou de instaurar em nossas terras, não para todo mundo, evidentemente, um imenso enclave europeu, mas americano, levando o colonizador a transplantar e a copiar tudo, criando réplicas e mais réplicas da Ibéria e de outras regiões da Europa: desde o instituto da escravidão, aqui reinventada numa escala nunca vista antes, até o aparato administrativo do estado colonial, além das próprias instituições do ensino e da propagação da fé católica.

Cabe então perguntar qual o lugar da filosofia na sociedade colonial e como se deu sua implantação, desde a sociedade nascente, numa colônia de poucas letras e avassalada pela pressão de começar tudo e sobreviver num meio em todos os aspectos estranho e hostil. E mais ainda: numa colônia longe de tudo e de todos, a quase $8.000 \mathrm{~km}$ da Europa, vivendo os colonizadores por aqui, no início, na época das feitorias, como conde-

${ }^{44}$ Para o conjunto das referências, ver Idem, p. 18-19. 
nados e degredados, não como prêmio e em reconhecimento pelos serviços prestados a El Rei - o que só acontecerá depois, com a estabilização da colônia de povoamento e o regime da escravidão, ao dar lugar ao senhorio e à casa grande \& senzala. Sou eu que estou dizendo isso, não Pe. Vaz, mas é esse o contexto e é o que está em jogo.

Voltando mais uma vez ao artigo da SEAF, ao retomar-lhe o tópico da filosofia colonial (estou me referindo à retomada pelo artigo da Síntese), porém desta feita mais bem equipado conceitualmente e com mais lastro e informação histórica - ainda que não o bastante, como viu-se antes, e ponto ao qual voltarei na conclusão deste ensaio -, a filosofia que aqui chegou e se difundiu nesse vasto período é uma filosofia rala e de segunda mão, e neste sentido ajustada à cultura rala e sem vida da Colônia. Segundo o filósofo mineiro, uma filosofia ensinada e difundida à base dos mesmos manuais - mais tarde conhecidas como "sebentas" - usados pela Companhia na Ibéria e em outras partes do mundo. Deste juízo severo não escapa nem mesmo a famosa tese defendida no Colégio dos Jesuítas do Rio de Janeiro e hoje guardada como raridade na Biblioteca da FAJE em Belo Horizonte: precisamente, a tese de um certo Francisco Fraga e orientada por Francisco de Faria, a qual segundo Pe. Vaz "pode ter algum interesse para a História da Filosofia Escolástica na Companhia de Jesus, mas - pergunta ele - que relação apresenta com a sociedade colonial? Nenhuma", responderá taxativo, e isto porque "essas mesmas teses, provavelmente, eram defendidas na mesma época nos Colégios dos Jesuítas de Viena ou de Praga" ${ }^{45}$.

Em suma é isso, tanto nos manuais ou "sebentas" quanto nas teses e em outros trabalhos de conclusão de curso, para a obtenção dos títulos de licença em filosofia e de doutor em teologia - tal foi o caso do Pe. Antônio Vieira, cuja formação se deu inteiramente na Colônia, no Colégio da Companhia de Salvador, na Bahia -, estamos diante da mesma fôrma das produções da Companhia na Península e em outros países da Europa, e, enquanto tais, com a mesma fôrma e o mesmo selo (imprimatur) transplantados e, mais ainda, replicados em terras americanas. E, de resto, sem nenhuma originalidade e calibragem para o nosso meio, situação que em vez de espantar ou causar espécie deve ser vista como normal e ajustada a um meio em que não vicejava nada, como na sociedade colonial, sem densidade cultural que pudesse alimentar uma filosofia própria ${ }^{46}$, o mesmo ocorrendo com o período pós-independência e da República Velha. De uma parte, por causa da estrutura da sociedade colonial e pós-colonial, com uma elite minúscula e uma massa enorme de analfabetos, inclusive na classe senhorial, como viu Gilberto Freyre. De outra parte, porque a alternativa ao ensino dos Colégios da Companhia, quando ela foi embora,

\footnotetext{
${ }^{45}$ Idem, p. 19-20.

${ }^{46}$ Idem, p. 20.
} 
não pareceu melhor com as escolas régias e as poucas faculdades que foram implantadas no período imperial: um pouco mais de meia dúzia, como as duas de medicina na Bahia e no Rio de Janeiro, as duas de direito em Olinda/Recife e em São Paulo, e as de engenharia do Rio e a de Minas em Ouro Preto, a última criada já no fim do Segundo Reinado por iniciativa de Dom Pedro II - e nenhuma faculdade de ciências humanas e letras, nos moldes das existentes na Europa, nos Estados Unidos e mesmo na América Hispânica. Ora, esta situação de grande indigência só vai ser alterada no curso do século XX, com a criação da Universidade de São Paulo e de sua branche em ciências humanas, a FFLCH, em 1934. O resto da história nós conhecemos, a implantação da filosofia acadêmica, com Pe. Vaz voltando mais uma vez ao artigo da SEAF e trocando a tópica dos lugares da filosofia pela agenda das disciplinas e áreas da filosofia: curiosamente, sem se referir à metafísica ou à ontologia, devido talvez à sua índole abstrata e universal, não tendo nada a ver com realidades e conjunturas, e focalizando [i] a filosofia social e política, [ii] a epistemologia da ciência da história mais a rival filosofia da história, [iii] a filosofia da literatura, à qual poderíamos acrescentar as artes, e, para terminar, [iv] a filosofia da ciências naturais, em cuja extensão poderíamos colocar a filosofia da tecnologia, na esteira do artigo da SEAF e de outros escritos.

Concluindo, Pe. Vaz lembra as duas perguntas que o guiaram ao longo dessas reflexões, na origem uma palestra, agora um artigo: "qual a significação da Filosofia no momento atual da história brasileira? (...) a figura histórica do filósofo e o ato de filosofar encontram legitimação social e cultural no Brasil de hoje?"

A resposta é sim, segundo ele, estando o país, depois desse longo percurso em busca de sua identidade, às voltas com "a própria reivindicação de sua originalidade" no concerto das nações, integrado na "cultura ocidental" em suas origens gregas e reconhecendo "na Filosofia sua suprema instância de racionalidade" ${ }^{\prime \prime 7}$. Esta é a situação e à qual deve ser acrescentada a situação do nosso país que é hoje "uma das sociedades mais dramaticamente injustas entre quantas existem sobre a face da terra", cuja solução - Pe. Vaz está a falar de justiça social - não poderá ser uma questão meramente técnica e ser mensurada em termos de barragens, usinas e PIB crescendo. Mas outra coisa, mediante parâmetros diferentes, e de ordem qualitativa antes de tudo (qualidade de vida da população), ao considerar o ethos da sociedade patriarcal erigido sobre a exclusão e a dominação que moldaram a sociedade brasileira desde a Colônia, dirá ele, ao reparar a lacuna deixada nas páginas precedentes: num contexto como o nosso, e com estas características, tal deve ser o papel do filósofo, preconiza o ilustre jesuíta, tanto o de pensar a situação quanto o de ajudar a modelar as alternativas

${ }^{47}$ Idem, p. 24. 
e, como tais, mais viáveis e ajustadas à "forma mais alta de racionalidade que é racionalidade do consenso, da convivência justa" 48 , entrando na linha de discussão "os problemas da qualidade de vida, dos fins éticos, dos valores de solidariedade e justiça" - coisa que só a filosofia pode fazer e "equacioná-los adequadamente" 4 .

Donde as duas assertivas finais de Pe. Vaz. A primeira: "A cultura filosófica e o exercício da reflexão filosófica tem, assim, definido seu lugar social no Brasil de hoje. E é um lugar que ouso apontar como elevação sobre a realidade fragmentária e aparentemente caótica, de onde ela pode ser abrangida em visão sinótica; onde os fins da sociedade podem ser pensados e descortinadas as direções de um caminho que seja historicamente viável" ${ }^{\prime 50}$. A segunda: trata-se como viu Sócrates ao perguntar pela forma de vida e o mundo dos homens sobre o que é o justo e o injusto, uma questão ética e política, em suma, e "numa sociedade como a do Brasil atual estou convencido de que a vocação de filósofo vem carregada com uma enorme responsabilidade social. Fazer filosofia com honestidade e lucidez, com energia e aturado esforço intelectual é uma exigência de justiça para conosco mesmos e para com o povo brasileiro" ${ }^{51}$.

Estas assertivas finais levam à consideração da outra face de Pe. Vaz como pensador e como intelectual, desta feita ao pensador e ao intelectual público. Esta face, hoje meio escondida, como o outro lado da lua, foi focalizada por mim em Filosofia no Brasil - Legados e perspectivas, a exemplo de outros connaisseurs deste lado de sua obra e biografia, como Paulo Arantes, ocasião em que eu atinei os leitores para os aspectos filosóficos de seu engajamento social e político. Tais aspectos eu evidenciei ao analisar o famoso Documento-base da Ação Popular (AP), publicado pela revista Verbum (PUC-RJ) em 1964, várias vezes citado, do qual ele foi um dos mentores e foi o responsável pelos dois capítulos iniciais do Documento, com destaque para o segundo que trata daqueles aspectos. Como eu mostrei, em uma de suas vertentes encontrando o personalismo de Mounier, em outra o humanismo integral de Maritain.

Ao voltar Documento mais uma vez, acrescento que dentre aqueles aspectos, subjacente às análises, vamos encontrar um mix da Nouvelle théologie e da filosofia francesa que se acostuma juntar com a etiqueta "Espiritualismo francês" - expressão que Pe. Vaz evita, como assinalado -, em cujas hostes iremos encontrar um pouco de tudo, em suas vertentes laicas e cristãs, entre estas os nomes de Maurice Blondel, Jacques Maritain, Emmanuel Mounier e Gabriel Marcel. No caso do Documento-base, em especial o se-

\footnotetext{
${ }^{48}$ Ibidem.

${ }^{49}$ Idem, p. 25.

${ }^{50}$ Ibidem.

${ }^{51}$ Ibidem.
} 
gundo capítulo mencionado, um estudioso atento com alguma familiaridade com a obra de Pe. Vaz e esta vertente da filosofia francesa contemporânea, abarcando o existencialismo cristão, o neotomismo e o personalismo, com suas mensagens humanistas, não terá dificuldades em reconhecer as influências notórias de Maritain e Mounier, as quais reitero mais uma vez e acrescento duas observações: Maritain, com seu humanismo integral e o método Ver, Julgar e Agir, referido na Introdução, $2^{\circ} \S$, e que era uma espécie de catecismo de todo mundo que entrava para a AP e a JUC; Mounier, com o personalismo, definido pela centralidade da pessoa visada em seus lados individual e social, ao renovar um tema fundamental da cristandade (as três pessoas da Santíssima Trindade) e que Vaz considerava essencial, juntamente com o humanismo integral, para se demarcar do marxismo e dar uma mensagem propriamente cristã às investidas do cristianismo social no mundo da política.

Creio que é o bastante e já é tempo de concluir o presente ensaio.

Sobre a Nouvelle théologie e a sua relação com o Documento-base, o leitor interessado nesse lado do pensamento e da obra do filósofo fará farta colheita ao prospectar seus escritos sobre "Cristianismo e consciência histórica" e sobre as Encíclicas de João XXIII vindo a lume no início dos anos sessenta: especialmente Pacem in Terris e Mater et Magistra, cujas conexões com a Nouvellle théologie e desta com o Concílio Vaticano II são reconhecidas pelos estudiosos e o próprio Pe. Vaz.

Sobre a $\mathrm{AP}$, a JUC e o Documento-base da $\mathrm{AP}$, será preciso considerar, como já foi lembrado, seu afastamento posterior, seu recolhimento em Belo Horizonte e seu conservadorismo em política, desconfiado do marxismo e com grandes reservas à teologia da libertação, de medo de o cristianismo ser engolido pelo marxismo ${ }^{52}$. E não obstante tudo isso, eis que a preocupação com o engajamento social do filósofo está de volta em seu artigo de

\footnotetext{
${ }^{52}$ Sobre a Teologia da Libertação e sua relação com o marxismo, as reservas são de ordem doutrinal, extrapolando a questão política e o suposto conservadorismo do filósofo. Em suas grandes linhas, o problema passa doutrinariamente pelo alinhamento, na perspectiva de Pe. Vaz, da teologia com a filosofia, não com as ciências humanas, como se deu com a Teologia da Libertação. O problema então é esse, a troca, com a ciência sendo procurada do lado do marxismo. Teremos então dois problemas: uma teologia rala, sem filosofia; uma teologia pseudo-cientifica, com o marxismo fazendo as vezes de ciência, mas que não passa de uma ideologia rasa e de segunda mão, uma espécie de vulgata para uso político, nada mais. Sobre este ponto, cf. o trecho à p. 32-33 da entrevista com Marcos Nobre, onde Vaz esboça suas reservas referentes à mistura da questão teológica com a questão política, chamando a atenção para o afastamento do catolicismo social do ideário da Conferência de Medellin, ocorrida em 1968, com a consequente radicalização e proeminência do marxismo, em busca de soluções que a teologia não pode dar. O resultado, segundo suas palavras, ao se reportar ao artigo "Cristianismo e utopia", foi o seu afastamento, já nos anos 80, quando o artigo veio a lume e republicado em Escritos de Filosofia I, datado de 1986. Conforme Vaz, ao concluir suas considerações, "No fundo, foi essa situação teórica ambígua que me manteve afastado da Teologia da Libertação" (p. 33).
} 
1984 focado no problema da filosofia no Brasil, ao falar da centralidade da justiça em Sócrates e em especial num país com as desigualdades abissais do Brasil. Tudo isso certamente conta e deve ser considerado ${ }^{53}$.

Sobre suas análises da filosofia nacional e da sociedade brasileira, ao prosseguir o balanço de suas investidas, haveria ainda muito que dizer sobre as deficiências analíticas de Pe. Vaz neste terreno especialmente difícil para o filósofo (estou falando em tese, não só dele), ao trocar o céu abstrato dos conceitos pelos desafios da realidade empírica, e num país com os problemas e as proporções do Brasil. Assim, especificamente no caso de Lima Vaz, deficiências metodológicas ao aplicar a tríade hegeliana do imediato, da mediação e da suprassunção, obscurecida e obliterada em suas análises da realidade, por não encontrar a unidade imediata que poderia servir de arranque, não havendo nenhum estado ético no período colonial nem unidade social primeva na sociedade colonial, fundada sobre a escravidão e a exclusão: caberia ver se o esquema da dialética hegeliana do senhor e do escravo se aplicaria à realidade brasileira e em que pontos ele deveria ser retificado, para ficar em pé ou não. Deficiências historiográficas e empíricas, devido à sua visão limitada da sociedade colonial e do período imperial pós-independência, levando-os a tomá-los em bloco, por se tratar da mesma sociedade patriarcal, mas ignorando os papeis diferentes da filosofia nas duas sociedades, prevalecendo uma filosofia diletante e autodidata no Império e orgânica e institucionalizada na Colônia. É o que mostram as descobertas recentes dos acervos de teses, licenças e disputationes do Colégio da Companhia de Jesus do Maranhão reunidas e estudadas por Lúcio Marques ${ }^{54}$, mas como negar que os estudos de Vaz - ainda que limitados às proporções de três artigos - lançam um importante facho de luz nesse campo de estudos e num tempo em que poucos de nós se dispunham a fazê-lo?

Sobre a originalidade de seu pensamento, depois de reconhecer ad nauseam a sua independência intelectual, com o filósofo mineiro alinhado à segunda atitude de nossa intelectualidade frente à matriz europeia (assimilação crítica, como antecipado no início deste ensaio), é hora de concluir e considerar em conjunto suas reflexões sobre a filosofia universal, em suas vertentes europeia e brasileira. Uma só segundo ele, reunidas sob

\footnotetext{
${ }^{53}$ Para uma boa retrospectiva da história da AP e do Documento, ver verbete AP, assinado por Mônica Kornis, já citado supra e disponível na Internet: bastante preciso, inclusive com respeito a datas, o verbete ressalta a fundação da AP em 1962, em Belo Horizonte, a liderança de Betinho [Herbert José de Souza], o papel de Pe. Vaz como mentor, tendo participado do $1^{\text {o }}$ Congresso em 1962 ao lado de Leonel Brizola e Almino Afonso, o embate com a alta hierarquia da Igreja e a vigência do Documento até 1967, quando consumou o afastamento da AP da esquerda católica e se deu sua aproximação com organizações marxista-leninistas e ainda maoístas.

${ }^{54}$ MARQUES, L.A. A lógica da necessidade. Porto Alegre, Ed. Fi, 2018, especialmente caps. III, IV e V.
} 
a etiqueta de filosofia ocidental e, por extensão, universal, como vimos, sem falar em eurocentrismo e coisas parecidas, por abranger os anseios e os problemas da humanidade inteira, qualquer que seja a etnia e a localização. Sobre a originalidade de seu pensamento e a atitude de independência intelectual, a supor que elas vão juntas, para a sua justa avaliação devemos nos livrar do fetichismo da criação absoluta, que não funciona nem mesmo nas artes, onde estamos diante de um hipertexto e tudo é correlativo - e, desde logo, prevalecendo criações relativas e datadas, não começos absolutos e novos pontos zeros na linha do tempo. Coisa que, rigorosamente, não fazia sentido para Pe. Vaz, ele que se colocava dentro da tradição filosófica e procurava pensar com ela, não contra ela. E foi o que ele fez, ao procurar imprimir em seu pensamento e em sua obra o selo da atitude crítica e do pensamento independente. Sapere aude, dizia Kant, e este foi o lema de Pe. Vaz, ao mergulhar na tradição, mas com independência, não com subserviência, e o resultado poderá ser tanto a reiteração de que outros já disseram, como em seu artigo sobre "Marxismo e filosofia", do qual ele disse na entrevista aos Cadernos de Filosofia alemã que tinha nada de original, porque apenas retratava para o leitor brasileiro posições defendidas pela intelectualidade francesa ${ }^{55}$. Mas como negar a potência e a originalidade de seu pensamento em suas antropologias filosóficas, com seu aparato metodológico estupendo e criação dele; em suas éticas filosóficas, ao coroar a ética clássica e a moral cristã, com o hegelianismo à testa do sistema ético, ao distinguir (e desenvolver) eticidade e moralidade; ou ainda em sua metafísica, com sua volta triunfal a Tomás Aquino em Raízes da modernidade?

Repetições, vulgarizações e alinhamentos, sim, eles não vão faltar, inclusive revisões, como no caso da experiência mística, indo das reservas iniciais até seu coroamento na categoria de espírito, como apex da experiência humana, na esteira de sua antropologia filosófica, como ele bem o mostra no livro publicado em 2000, ao se realinhar à tradição ocidental e católica - mas quem ousaria negar nestas retomadas e investidas a originalidade e a potência de sua obra e de seu pensamento?

Vida longa à memória de Pe. Vaz e o vaticínio de que, em nossa ausência, nós que tivemos o privilégio de conviver com ele, ler suas obras e assistir aos seus cursos, não vão faltar colegas e estudioso(a)s do futuro que irão revisitar e reconhecer sua obra, ao celebrar mais uma efeméride em honra de seu legado, daqui outros cem anos.

${ }^{55}$ VAZ, H.C. de Lima. Filosofia e forma de ação [Entrevista], op. cit., p. 95. De fato, três artigos, publicados em Síntese, 1959, e depois reunidos e republicados em Ontologia e história. 


\section{Referências bibliográficas:}

CRUZ COSTA, J. O pensamento brasileiro sob o império, in: HOLANDA, S.B. (Org.). História da civilização brasileira, v. II, t. 3 - O Brasil monárquico. São Paulo: DIFEL, 1976, p. 323-342.

DOMINGUES, I. Filosofia no Brasil - Legados e perspectivas. São Paulo, Ed. UNESP, 2017.

FLUSSER, V. "Miguel Reale, um testemunho", Revista Brasileira de Filosofia, jan.-fev.-mar., vol. XLII, fasc. 173, 1994, p. 7-14.

KORNIS, M. Verbete $A P$, hospedado em FGV-CPDOC e disponível na Internet.

LADUSÃNS, S. Rumos da filosofia atual no Brasil - Em auto-retratos, Loyola, 1976, v. 1, p. 297-311.

MAC DOWELL, J. A. (Org.). Mac Dowell Saber filosófico, história e transcendência. São Paulo: Ed. Loyola, 2002.

MARQUES, L.A. A lógica da necessidade. Porto Alegre, Ed. Fi, 2018.

MARTINS, W. "O pensamento reacionário", Estadão, Suplemento Literário, 19/12/1971.

NOBRE, M \& REGO. J.M. Conversas com filósofos brasileiros. São Paulo: Editora 34, 2000

VAZ, H.C. de Lima. "O pensamento filosófico no Brasil de hoje", Revista Portuguesa de Filosofia, v. 37, 1961, p. 235-273.

1962, p. 75-109.

“Consciência e realidade nacional", Síntese, vol. 4, n. 14, abr.-jun., jun., 1963, p. 8-33.

"A grande mensagem de João XXIII", Síntese, v. 5, n. 18, abr./

Acerca de "A formação marxista", Revista Vozes, v. 58, set., 1964, p. 641-651. (Cf. nota do Memorial Padre Vaz: "Carta ao redator da Revista Vozes Frei Aurélio Stulzer em defesa das posições tomadas no artigo "A grande mensagem de João XXIII" [Revista Síntese, v. 5, n. 18, abr./jun., 1963, p. 8-33], devido ao "ataque violento e injusto" dirigido por Alfredo Lage em seu artigo publicado na Revista Vozes, v. 59, n. 3, 1965, p. 191-213).

-“Filosofia no Brasil, hoje”, Cadernos SEAF, ano 1, n. 1, 1978, p. 7-17.

“'Crise' da PUC: Descendo às raízes", Revista Encontros com a Civilização Brasileira, 1979. 10, p. 13-18.

“O problema da filosofia no Brasil, Síntese, n. 30, 1984. p. 11-25.

Escritos de filosofia I. São Paulo: Ed. Loyola, 1986.

Escritos de filosofia II: Ética e cultura. São Paulo: Loyola, 1988.

"Antropologia tripartida e exercícios inacianos", Perspectivas

Teológicas, v. 23, n. 61, set./dez., 1991, p. 349-358.

Antropologia filosófica I. São Paulo: Loyola, 1991. 
Antropologia filosófica II. São Paulo: Loyola, 1992.

2, 1997, p. 77-102.

Filosofia e forma de ação [Entrevista]. Cadernos de Filosofia Alemã,

Loyola, 1999.

Escritos de filosofia IV: Introdução a ética filosófica 1. São Paulo:

Escritos de filosofia V: Introdução a Ética filosófica 2. São Paulo:

Loyola, 2000.

Loyola, 2000.

Experiência mística e filosofia na tradição ocidental. São Paulo:

Escritos de filosofia VI: Ontologia e história. São Paulo: Loyola, 2001 (Especialmente, os capítulos Itinerário da ontologia clássica, Marxismo e filosofia, Cristianismo e consciência histórica e $\mathrm{O}$ absoluto e a história, este inédito e os demais republicações de artigos).

Escritos de Filosofia VII: Raízes da modernidade. São Paulo: Ed. Loyola, 2002 (Inclui Presença Filosófica de Tomás de Aquino no horizonte filosófico do século XXI, publicado como artigo na revista Síntese em 1998).

VVAA Ação Popular: Documento-base, rev. Verbum, t. XXI, fasc. 1-2, mar.-jun., p. 67-95.

Endereço do Autor:

Rua Antônio Aleixo, 330 - Apto. 702

Lourdes

30180-150 Belo Horizonte - MG

domingues.ivan3@gmail.com 